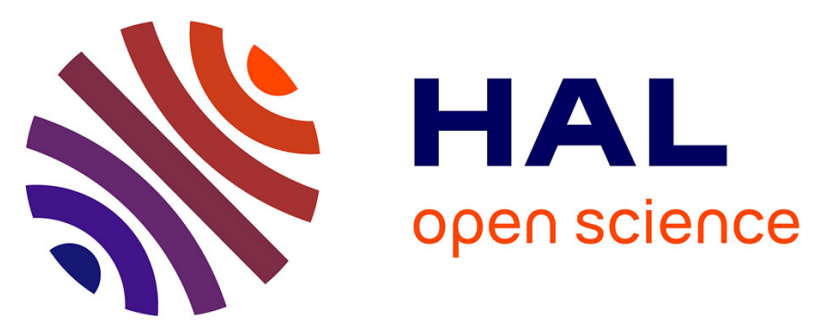

\title{
Analysis of meteorological variables in the Australasian region using ground- and space-based GPS techniques
}

Yuriy Kuleshov, Suelynn Choy, Erjiang Frank Fu, Fabrice Chane-Ming, Yuei-An Liou, Alexander G Pavelyev

\section{- To cite this version:}

Yuriy Kuleshov, Suelynn Choy, Erjiang Frank Fu, Fabrice Chane-Ming, Yuei-An Liou, et al.. Analysis of meteorological variables in the Australasian region using ground- and space-based GPS techniques. Atmospheric Research, 2016, 176, pp.276 - 289. 10.1016/j.atmosres.2016.02.021 . hal-01385214

\section{HAL Id: hal-01385214 \\ https://hal.univ-reunion.fr/hal-01385214}

Submitted on 21 Oct 2016

HAL is a multi-disciplinary open access archive for the deposit and dissemination of scientific research documents, whether they are published or not. The documents may come from teaching and research institutions in France or abroad, or from public or private research centers.
L'archive ouverte pluridisciplinaire HAL, est destinée au dépôt et à la diffusion de documents scientifiques de niveau recherche, publiés ou non, émanant des établissements d'enseignement et de recherche français ou étrangers, des laboratoires publics ou privés. 


\title{
Analysis of meteorological variables in the Australasian region using ground- and space-based GPS techniques
}

\author{
Yuriy Kuleshov a,b,c,d,*, Suelynn Choy ${ }^{\text {b }}$, Erjiang Frank Fu ${ }^{\text {a }}$, Fabrice Chane-Ming ${ }^{\text {e }}$ \\ Yuei-An Liou ${ }^{\mathrm{f}}$, Alexander G. Pavelyev ${ }^{\mathrm{g}}$ \\ a Bureau of Meteorology, Melbourne, Australia \\ b School of Science, RMIT University, Melbourne, Australia \\ c Faculty of Sciences, Engineering and Technology, Swinburne University, Melbourne, Australia \\ ' School of Mathematics and Statistics, The University of Melbourne, Melbourne, Australia \\ e Université de la Réunion, Laboratoire de l'Atmosphère et des Cyclones, UMR 8105, UMR CNRS-Météo France-Université, La Réunion, France \\ ${ }^{\mathrm{f}}$ Center for Space and Remote Sensing Research (CSRSR), National Central University, Jhongli, Taiwan \\ ${ }^{\mathrm{g}}$ Kotelnikov Institute of Radio Engineering and Electronics of the Russian Academy of Sciences, Fryazino, Russian Federation
}

\begin{abstract}
A B S T R A C T
Results of analysis of meteorological variables (temperature and moisture) in the Australasian region using the global positioning system (GPS) radio occultation (RO) and GPS ground-based observations verified with in situ radiosonde (RS) data are presented. The potential of using ground-based GPS observations for retrieving column integrated precipitable water vapour (PWV) over the Australian continent has been demonstrated using the Australian ground-based GPS reference stations network. Using data from the 15 ground-based GPS stations, the state of the atmosphere over Victoria during a significant weather event, the March 2010 Melbourne storm, has been investigated, and it has been shown that the GPS observations has potential for monitoring the movement of a weather front that has sharp moisture contrast. Temperature and moisture variability in the atmosphere over various climatic regions (the Indian and the Pacific Oceans, the Antarctic and Australia) has been examined using satellite-based GPS RO and in situ RS observations. Investigating recent atmospheric temperature trends over Antarctica, the time series of the collocated GPS RO and RS data were examined, and strong cooling in the lower stratosphere and warming through the troposphere over Antarctica has been identified, in agreement with outputs of climate models. With further expansion of the Global Navigation Satellite Systems (GNSS) system, it is expected that GNSS satellite- and ground-based measurements would be able to provide an order of magnitude larger amount of data which in turn could significantly advance weather forecasting services, climate monitoring and analysis in the Australasian region.
\end{abstract}

\section{Introduction}

Conventional observations of meteorological variables (air pressure, temperature and moisture) are collected daily at thousands of meteorological stations around the world, to be used for weather analysis and forecasting. Subsequent statistical analysis of the archived data over long-term period (decades and longer) allows one to derive conclusions about climate (average state of weather) based on instrumental records obtained at meteorological stations. Conventional observations are well established and archives of meteorological variables recorded at many stations worldwide go back for more than a century. Such continuity of records is crucial for climate research, detection of historical trends

\footnotetext{
* Corresponding author at: Bureau of Meteorology, GPO Box 1289, Melbourne 3001,
} Australia.

E-mail address: y.kuleshov@bom.gov.au (Y. Kuleshov). in meteorological variables, etc. However, conventional records are restricted to locations of meteorological stations.

In modern time, data obtained by optical, infrared, radio wave and microwave remote sensing instruments revolutionised the science of meteorology and climatology as they provide potentially global coverage and consequently improved access to areas which have limited number of meteorological stations (data sparse areas) or not covered by conventional observations at all. Remote sensing data complement conventional observations and are widely used in numerical weather prediction, for climate monitoring and analysis adding value to and improving skill of weather forecasts, the accuracy of trend analysis of meteorological variables, etc. It is of particular importance for meteorological and climatological applications in the Southern Hemisphere where weather observation stations are much less in numbers than in the Northern Hemisphere. In this study, we present results of analysis of meteorological variables over data sparse areas using the 
measurements obtained by ground- and space-based techniques which utilise radio signals of the global positioning system (GPS).

Atmospheric water vapour is a critical component of the greenhouse effect and plays a significant role in the global climate system. The knowledge of the long-term spatial and temporal variability of water vapour is vital for understanding climate change. Ground-based GPS has long offered the prospect of complementing meteorological observations by providing integrated vertical column of precipitable water vapour (PWV) estimates beginning with pioneering studies of Bevis et al. (1992, 1994). There have been numerous studies since, over the USA, Japan, Korea, Europe, India, Taiwan and Antarctica, which demonstrated usefulness of this methodology (Rocken et al., 1993; Seko et al., 2000; Liou and Huang, 2000; Liou et al., 2000; Liou et al., 2001; Jade et al., 2005; Zhang et al., 2007; Bock and Nuret, 2009). One of the most valuable attributes of ground-based GPS-PWV is the ability to provide high temporal resolution and high accuracy of PWV estimates under all weather conditions at a very low cost. In this paper, we present results of deriving PWV using ground-based GPS reference stations network and investigate potential of the GPS-PWV methodology for monitoring of weather fronts.

Space-based instruments provide even wider (potentially global) coverage than regional ground-based networks, including the world ocean which covers about 70\% of the Earth's surface. One of the emerging satellite remote sensing technique for obtaining atmospheric temperature and moisture records is GPS radio occultation (RO) methodology, which provides all-weather capability, long-term measurement stability, high vertical resolution and high-accuracy measurements in the middle to upper troposphere, stratosphere and ionosphere (e.g., Rocken et al., 1997; Heise et al., 2006; Liou et al., 2007, 2010; Pavelyev et al., 2013; Kumar et al., 2014; Santhi et al., 2014; Dhaka et al., 2015). The high accuracy of the GPS RO methodology is of particular importance for reliable estimates of the atmospheric characteristics over the regions where conventional meteorological upper air observations from radiosondes (RS) are sparse or not available.

Evaluation of GPS RO methodology for retrieval of atmospheric profiles has been conducted in a number of studies in various regions (Wickert, 2004; Kuo et al., 2005; Fu et al., 2007; Rao et al., 2009), and the high accuracy of retrieval of meteorological variables has been demonstrated. He et al. (2009) used GPS RO data to assess the accuracy of temperature measurements by four types of RS in the upper troposphere and low stratosphere and demonstrated a close-to-zero mean difference between GPS RO and RS data for two types of radiosonds, Vaisala-RS92 and Shanghai radiosonde systems. However, large temperature biases are shown for the MRZ and VIZ-B2 radiosonde systems relative to GSP RO, which are probably caused by diurnal radiative effects (He et al., 2009).

This study is concerned with analysis of meteorological variables in the Australasian region (continent of Australia, Maritime continent, the Indian and the Pacific Oceans) and the Antarctic, which are much less covered by meteorological observations than the Northern Hemisphere. Specifically, the state of the atmosphere over the Australasian region and the Antarctic is investigated. The Australasian region is highly important in terms of impacts on weather and climate. The region is significant in meteorology because it is considered the most important energy source region in the entire global circulation system owing to a number of coincident factors, the most significant being geographical location and topography, both of which contribute to the development of the warmest large area of ocean on the Earth, the Tropical Warm Pool (Graham, 1994; Zhang et al., 1997). This is a region of intensive ocean-atmosphere interaction with widespread convection and environment favourable for tropical cyclone development. El Niño-Southern Oscillation (ENSO), a coupled ocean-atmosphere phenomenon in the central Pacific (Trenberth, 1997), is another significant climate driver of the planet, which causes extreme weather (such as floods and droughts) in many regions of the world (Nicholls, 1993; Kuleshov et al., 2014). The Indian Ocean Dipole (IOD), a phenomenon which is similar to the ENSO in the Pacific, involves an aperiodic oscillation of sea-surface temperatures and atmospheric pressure in the Indian Ocean (Saji et al., 1999), and its positive phase is associated with droughts in adjacent land areas of Indonesia and Australia. Consequently, accurate knowledge about the state of the atmosphere over the Indian and the Pacific Oceans is vital for understanding the ENSO and the IOD and their impacts on climate of the Australasian and other regions of the planet. Here we present analysis of collocated GPS RO and

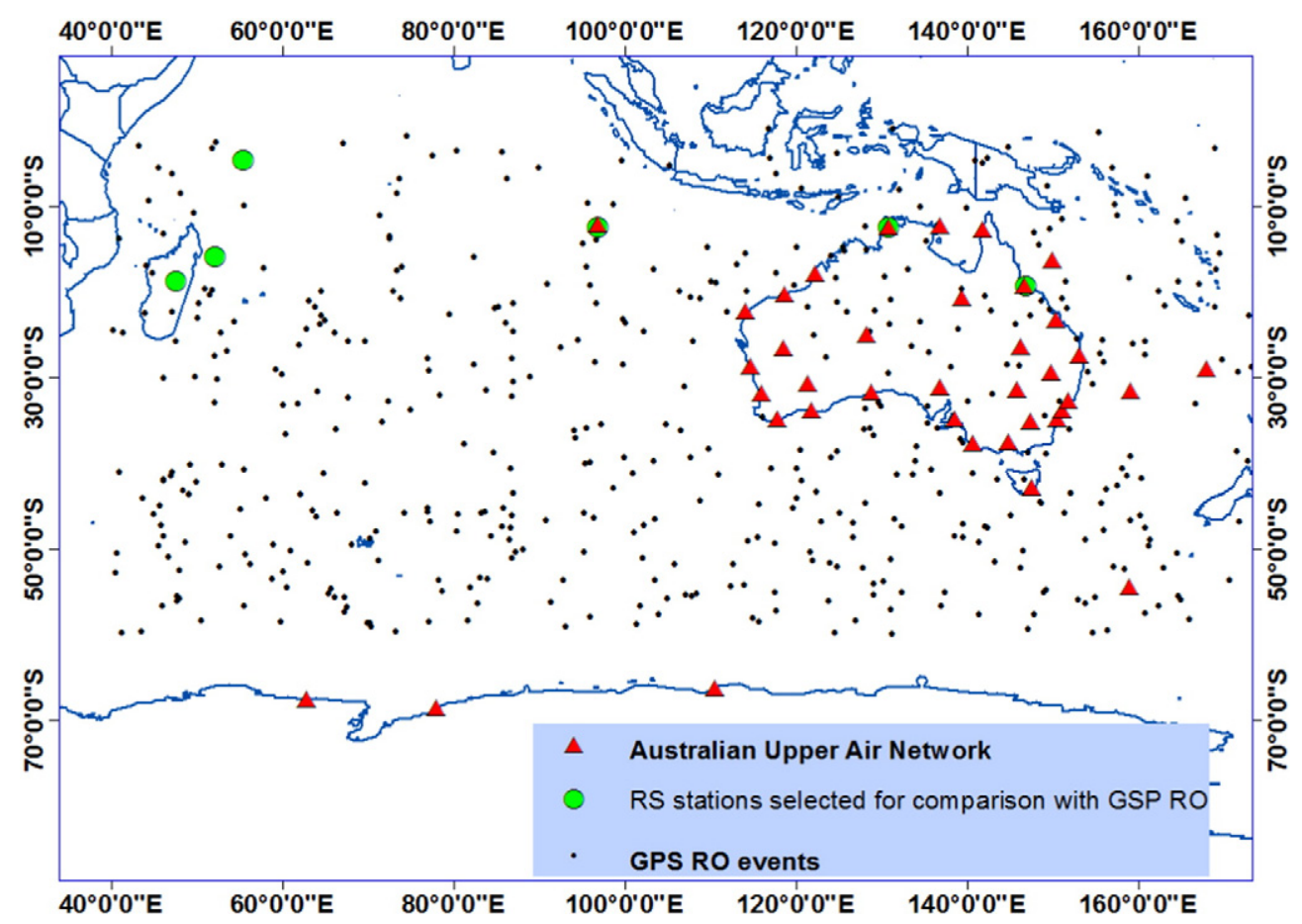

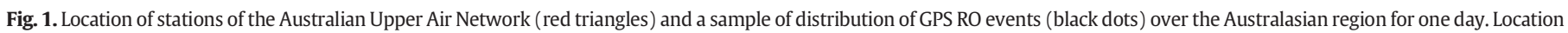
of six RS stations in the tropics selected for comparison with GPS RO are highlighted by green circles. 
Table 1

Geographical location of RS stations, number of RS and GPS RO atmospheric profiles and number of collocated profiles obtained from May 2006 to December 2010.

\begin{tabular}{lll}
\hline \multirow{2}{*}{$\begin{array}{l}\text { Radiosonde station } \\
\text { (latitude, longitude) }\end{array}$} & Number of profiles & \\
\cline { 2 - 3 } & RS/GPS RO profiles & Collocated profiles \\
\hline Antananarivo $\left(-18^{\circ} 48^{\prime}, 47^{\circ} 29^{\prime}\right)$ & $2683 / 1616$ & 700 \\
Tromelin $\left(-15^{\circ} 53^{\prime}, 52^{\circ} 11^{\prime}\right)$ & $1306 / 1314$ & 244 \\
Mahe $\left(-4^{\circ} 37^{\prime}, 55^{\circ} 27^{\prime}\right)$ & $2390 / 785$ & 306 \\
Cocos Island $\left(-12^{\circ} 30^{\prime}, 96^{\circ} 50^{\prime}\right)$ & $1649 / 897$ & 269 \\
Darwin $\left(-12^{\circ} 25^{\prime}, 130^{\circ} 50^{\prime}\right)$ & $6730 / 983$ & 949 \\
Townsville $\left(-19^{\circ} 15^{\prime}, 146^{\circ} 49^{\prime}\right)$ & $5142 / 1546$ & 1178 \\
\hline
\end{tabular}

in situ RS data over the Indian and the Pacific Oceans to demonstrate the accuracy of GPS RO retrieval of atmospheric temperature and moisture profiles in the tropics.

The climate of Antarctica is the coldest on the Earth, with the lowest near-surface temperature of $-89.2{ }^{\circ} \mathrm{C}$ recorded at Vostok Station (Budretsky, 1984). However, due to a global warming, near-surface and air temperatures in Antarctica are rapidly increasing. Positive trend in near-surface temperature is well documented and significant warming of the Antarctic Peninsula was observed (King, 1994; Vaughan et al., 2001). Assessment of Antarctic near-surface temperature change has shown that significant warming extends well beyond the Antarctic Peninsula to cover most of West Antarctica. West Antarctic warming exceeds $0.1{ }^{\circ} \mathrm{C}$ per decade over the past 50 years and is strongest in winter and spring (Steig et al., 2009). Although this is partly offset by autumn cooling in East Antarctica, the continent-wide average near-surface temperature trend is positive. Analysing a complete temperature record for Byrd Station, a linear increase in annual temperature between 1958 and 2010 by $2.4 \pm 1.2^{\circ} \mathrm{C}$ has been found, establishing central West Antarctica as one of the fastest-warming regions globally (Bromwich et al., 2012). In fact, significant warming extends well beyond the Antarctic Peninsula and covers most of West Antarctica (Steig et al., 2009). However, there is no agreement on magnitude of atmospheric temperature trends over the Antarctic. Thus, reliable satellite remote sensing data are crucial for accurate estimation of atmospheric temperature variability over the vast areas of the Antarctic.

The total precipitation in Antarctica, averaged over the entire continent, is about $166 \mathrm{~mm}$ per year (Vaughan et al., 1999). According to the Köppen climate classification, areas that receive less than $250 \mathrm{~mm}$ of precipitation per year are classified as deserts. As such, the continent of Antarctica is largely a desert, apart from coastal areas with higher rate of precipitation. Thus, the air over Antarctica is generally very dry, and the potential accuracy of air temperature estimates as derived from GPS RO observations is high as the retrieval algorithm depends on amount of moisture content (Rocken et al., 1997; Kuo et al., 2004). Here we present analysis of vertical distribution of atmospheric temperature over polar region (Antarctica) derived from GPS RO observations, to give another example of value of remote sensing data for providing essential upper air data in the Southern Hemisphere where RS network is extremely sparse.

\section{Data and methods}

To analyse the state of the atmosphere over the Australasian region, we used GPS RO data from FORMOSAT-3/COSMIC (F3C) mission. F3C is the first GPS RO mission that employs a satellite constellation for RO observations and the constellation consists of six Low Earth Orbit satellites (Liou et al., 2007; Fong et al., 2008a, 2008b, Wickert et al., 2009). F3C was launched in 2006, and the constellation is currently operational providing a large number of daily observations. GPS RO data from F3C constellation were obtained from COSMIC web site http://www. cosmic.ucar.edu/. We analysed GPS RO temperature and moisture profiles obtained by F3C constellation over the Australasian region. Six

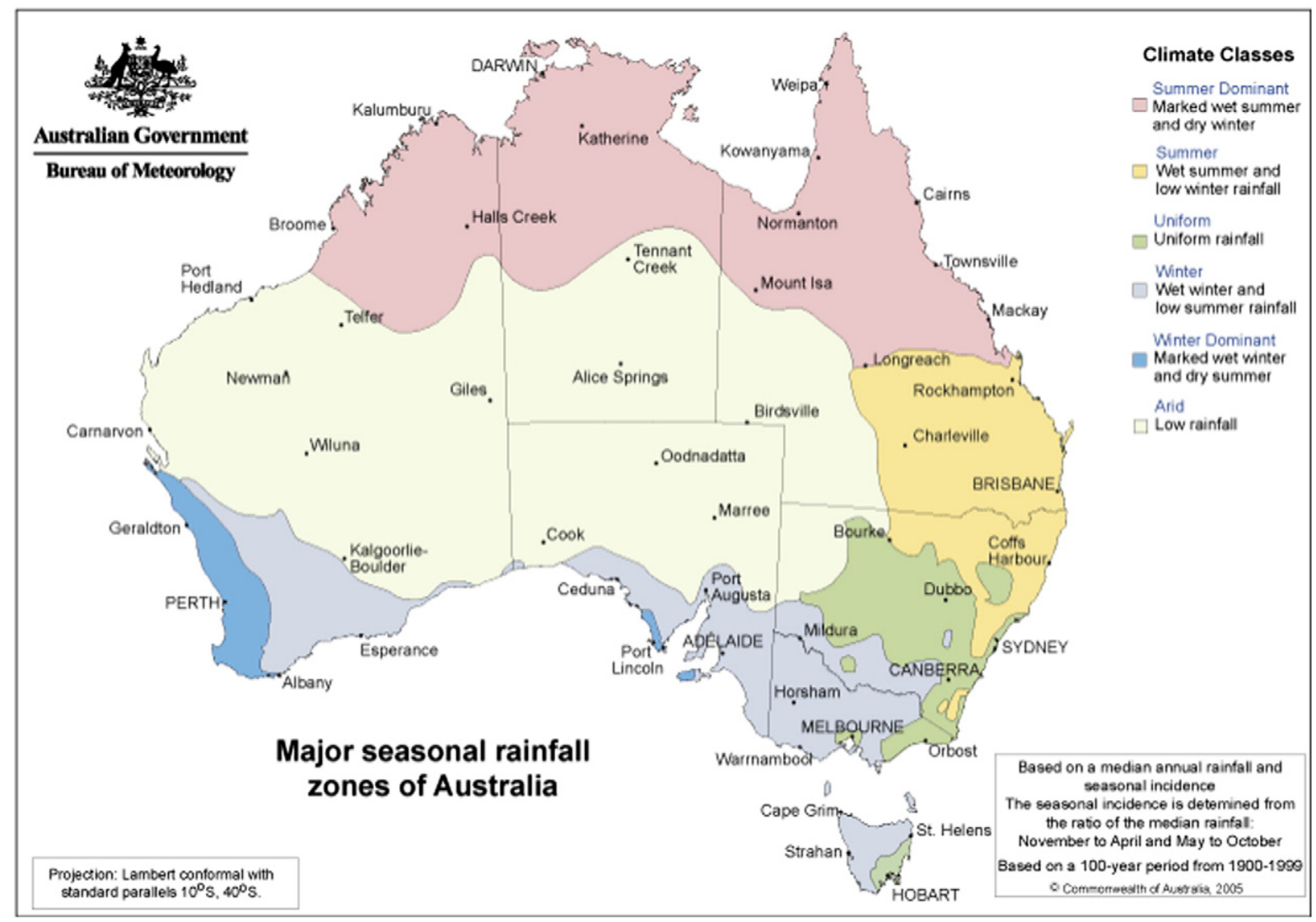

Fig. 2. Major seasonal rainfall zones of Australia. 


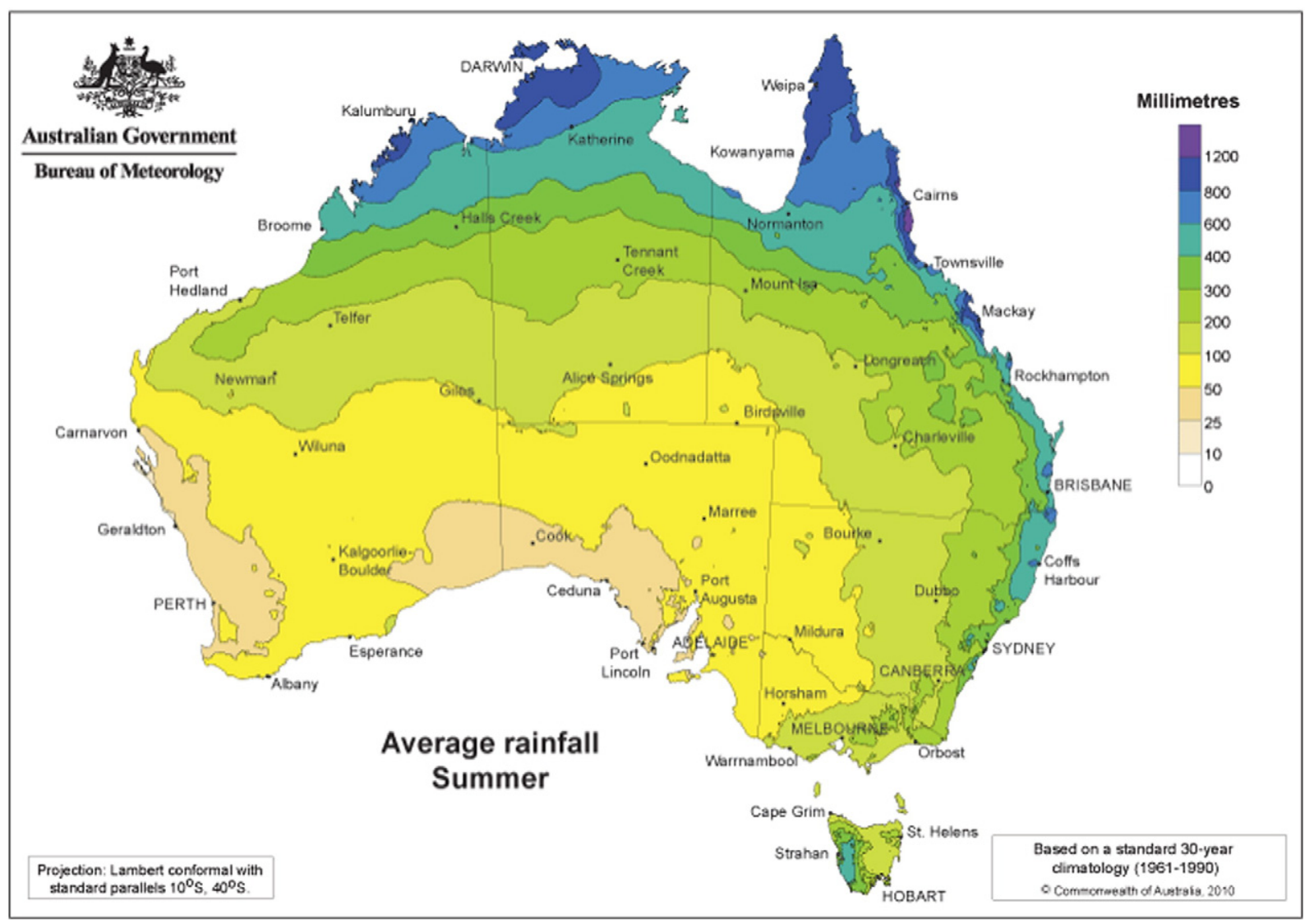

Fig. 3. Average summer rainfall across Australia over the period 1961 to 1990.

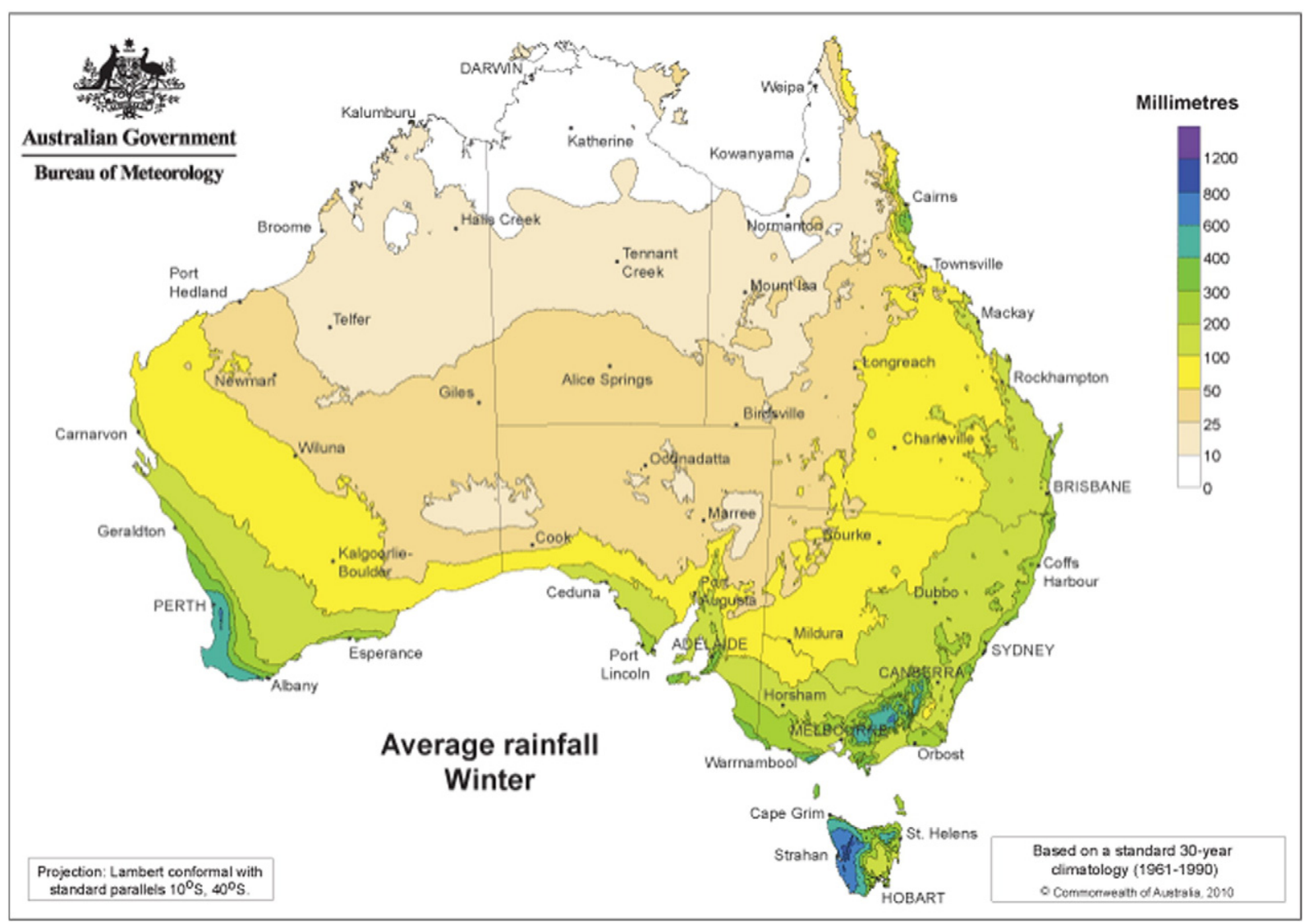

Fig. 4. Average winter rainfall across Australia over the period 1961 to 1990 
meteorological stations located in the tropics and having high quality of RS records have been selected for comparison (Fig. 1, the selected stations are highlighted by green circles). Five years of RS data (20062010) have been compared with GPS RO collocated events. In this study, GPS RO collocated profiles have been selected to satisfy criteria of (i) spatial collocation to be within $300 \mathrm{~km}$ radius from geographic position of the meteorological site, and (ii) temporal collocation to be less than $3 \mathrm{~h}$ before or after the time of RS launch (spatial and temporal collocation criteria have been defined based on results of Zhang et al., 2011). The number of atmospheric profiles for RS and GPS RO events at the selected tropical sites is presented in Table 1.

Tropical air over the Australian region is generally warm and moist; however, there is a distinct seasonality. In the Southern Hemisphere, November to April is a wet season and May to October is a dry season; this is translated into significant difference in distribution of rainfall, atmospheric moisture and temperature (for detail, see Zillman, 2001; Kuleshov, 2004). In terms of seasonal rainfall, the climate of Australian tropics is classified as summer dominant, with marked wet summer and dry winter (Fig. 2). In this classification, the differences between summer and winter rainfall (Figs. 3 and 4, respectively) are used to identify six major climate zones. In Fig. 2, the median annual rainfall and seasonal incidence (the ratio of the median rainfall over the period November to April to the period May to October) is used to identify these six major zones across Australia. As evident from Figs. 3 and 4, in the tropics, most of the rainfall occurs in the summer months and it is associated with the monsoon. Based on this classification, we stratified the observations between wet seasons, which also corresponds to tropical cyclone (TC) seasons (November to April) and dry, non-TC seasons (May to October).
To evaluate vertical distribution of atmospheric temperature over the Antarctic, we used GPS RO data obtained from the Challenging Minisatellite Payload (CHAMP) for geoscientific research mission (Wickert et al., 2001). CHAMP was launched in 2000, and for a decade, the mission has been operational. As long records are essential to estimate climate change accurately, CHAMP data were selected to derive temperature trends over Antarctica. We use CHAMP data processed by UCAR (Level 2 wetPrf data from May 2001 to August 2008 available online at http://www.cosmic.ucar.edu/). CHAMP GPS RO data were analysed at nine pressure levels $(850,700,600,500,300,200,150$, 100 and $50 \mathrm{hPa}$ ) and compared with RS data obtained at seven Antarctic meteorological stations.

To investigate the potential of using ground-based GPS observations for retrieving vertical column integrated PWV over the Australian continent, we utilised the data from the Australian GPS reference stations network, e.g., the State of Victoria GPSnet (Department of Environment and Primary Industries, 2013). The GPS-based methodology can be used for retrieving column integrated PWV profiles from the time-varying tropospheric zenith path delay, which can be retrieved by stochastic filtering of the GPS measurements (Bevis et al., 1992). In this study, the GPS-PWV estimates were derived using the GPS meteorology method originally proposed by Bevis et al., 1992, 1994. GPS signals are delayed when propagating through the troposphere, and this delay is known as the zenith path delay (ZPD) or the zenith total delay (ZTD). The conversion from ZTD to PWV involves a two-step process. The ZTD is divided into a hydrostatic term (known as zenith hydrostatic delay, ZHD) caused primarily by the dry gases in the atmosphere and a wet term (known as zenith wet delay, ZWD), which is mainly contributed by water vapour contained in the atmosphere (Davis et al.,

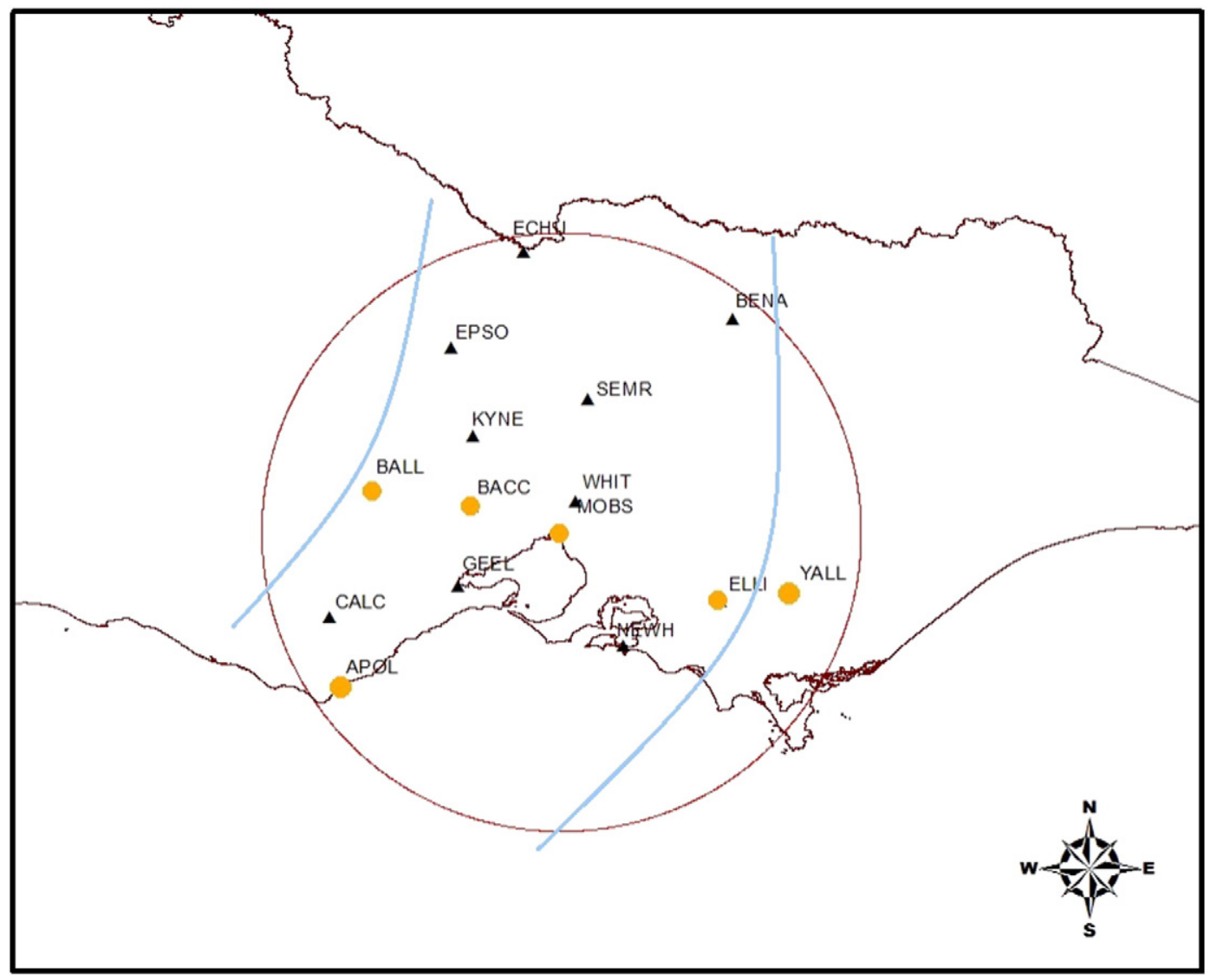

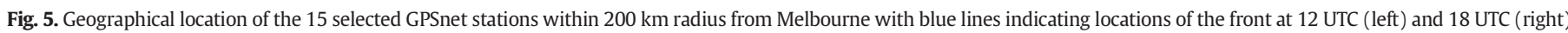
(DOY 064, 5 March 2010), respectively. 


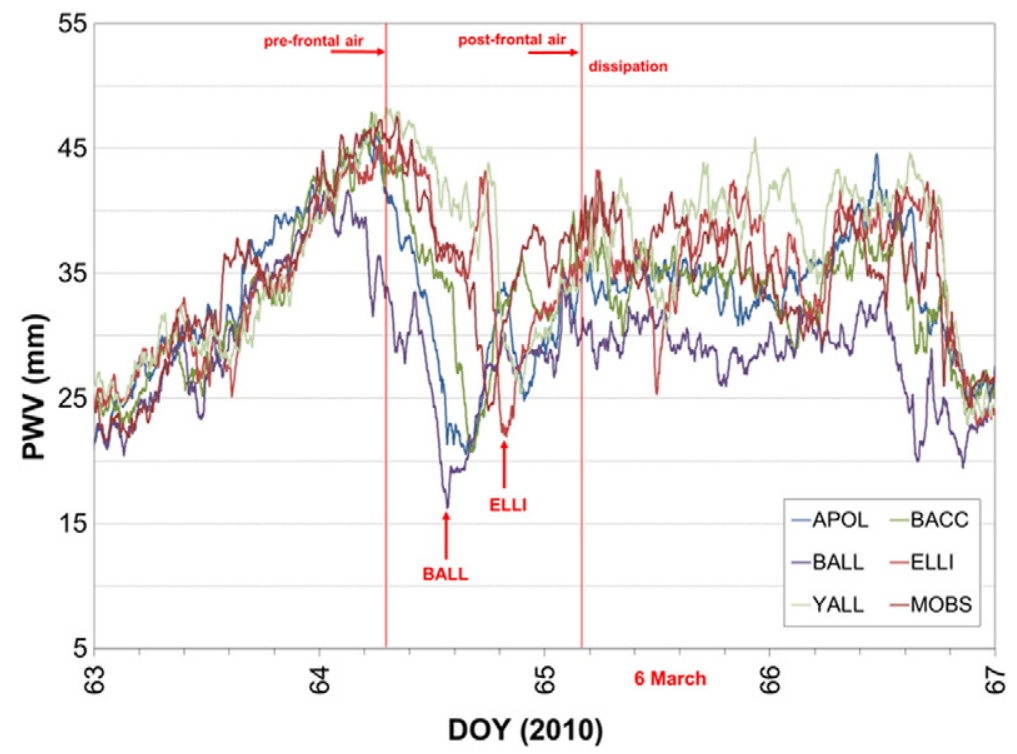

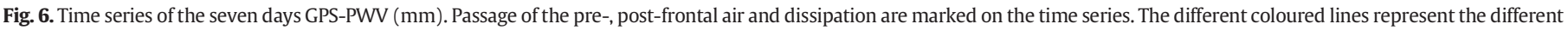
GPS stations marked in the figure on the right.

1985). ZHD can be calculated given the local surface pressure and known location of the GPS receiver. Subtracting ZHD from ZTD yields ZWD, from which PWV can be estimated given near-surface air temperature. In our study, the ground-based GPS-derived PWV are integrated vertical column water vapour.

To validate remote sensing data obtained by F3C and CHAMP space missions and the Australian GPS reference stations network, we used conventional upper air observations obtained by RS. For meteorological stations located on the Australian continent, the RS data were obtained from archive of the National Climate Centre, the Australian Bureau of Meteorology. In Fig. 1, the location of observation stations of the Australian Upper Air Network is presented. For the stations in Antarctica, RS records (monthly time series) were extracted from the HadAT2 data set of the Hadley Centre, UK Met Office (Thorne et al., 2005), available online at http://hadobs.metoffice.com/hadat/hadat2.html.

RS is the primary operational source of upper air observations, including pressure, temperature and moisture; for this reason, they are used for independent validation of GPS-PWV and GPS RO data. An RS flight ascends to $2 \mathrm{~km}$ in 7-8 min and reaches $5 \mathrm{~km}$ in about $20 \mathrm{~min}$ after the launch. As the temporal variability of the GPS-PWV and GPS $\mathrm{RO}$ in these time scales is not significant, GPS-derived values are often

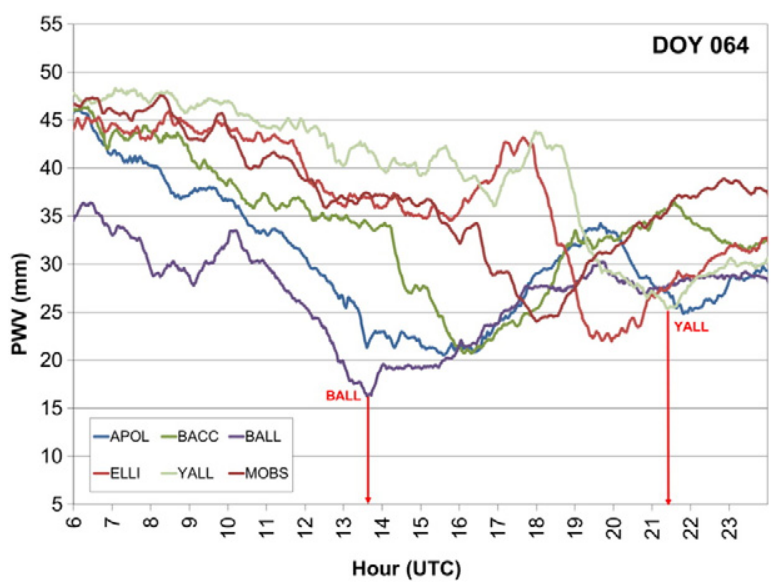

Fig. 7. A close-up snapshot of the GPS-PWV results from six GPS stations during the passage of the weather front eastward through Greater Melbourne on DOY 64 (5 March 2010). The different coloured lines represent the different GPS stations marked in the figure on the left. taken at times when RS flights are released (e.g., 11:00 UTC and 23:00 UTC). It is these values of RS data that were used for comparison with GPS-PWV and GPS RO data using the collocation criteria described above.

While coastal areas of Australia are reasonably covered by the RS network, the geographic distribution of the stations in the interior of the continent is very sparse. Similarly, vast areas of the Indian Ocean, the Pacific Ocean and the Antarctic are covered by only a few stations. On the other hand, satellite-based measurements provide global coverage and thousands of atmospheric pressure, temperature and moisture profiles could be obtained daily over remote areas with limited conventional observations. For example, F3C provides approximately 2500 daily GPS RO events globally. This is a comparable amount of atmospheric profiles to those obtained by the global RS network, which has about 2000 stations worldwide. On average, the Australasian region obtains around $300 \mathrm{RO}$ events daily (Fig. 1), which is more than a number of atmospheric profiles that 38 Australian RS stations provide. Similarly, ground-based Australian GPS/GNSS reference stations network provides observations of much higher density (and frequency) than the upper air stations network (RS are typically launched only once or twice a day). For example, there are 15 GPSnet stations in Victoria within a $200-\mathrm{km}$ radius from central Melbourne and only one RS station. Thus, remote sensing methodologies, which provide the high accuracy of retrieval of meteorological variables, have great potential not only to complement conventional observations but in the near future to become a superior source of data for meteorology and climate research and applications.

In the next section, we present results of the GPS ground- and spacebased atmospheric moisture and temperature retrievals validated with in situ RS data to demonstrate value of these remote sensing methodologies for detailed description of vertical structure of the atmosphere in various climatic regions (from the tropics to polar areas), potential for enhancing severe weather forecasting and deriving accurate estimates of atmospheric temperature trends.

\section{Results}

3.1. Atmospheric moisture retrieval over the Australian continent from GPS ground-based and RS data

We verified the accuracy of GPS-PWV data using RS data at two sites of the Australian Bureau of Meteorology Upper Air Network. The 
selected meteorological stations were Melbourne Airport in Victoria and Wagga Wagga in New South Wales located within close proximity to the GPSnet stations-Melbourne Observatory (MOBS) and Wagga
Wagga (WGGA). The separation distance is $22 \mathrm{~km}$ between MOBS and Melbourne Airport RS site and $10 \mathrm{~km}$ between WGGA and Wagga Wagga RS site. As for height difference, it is $78 \mathrm{~m}$ between Melbourne
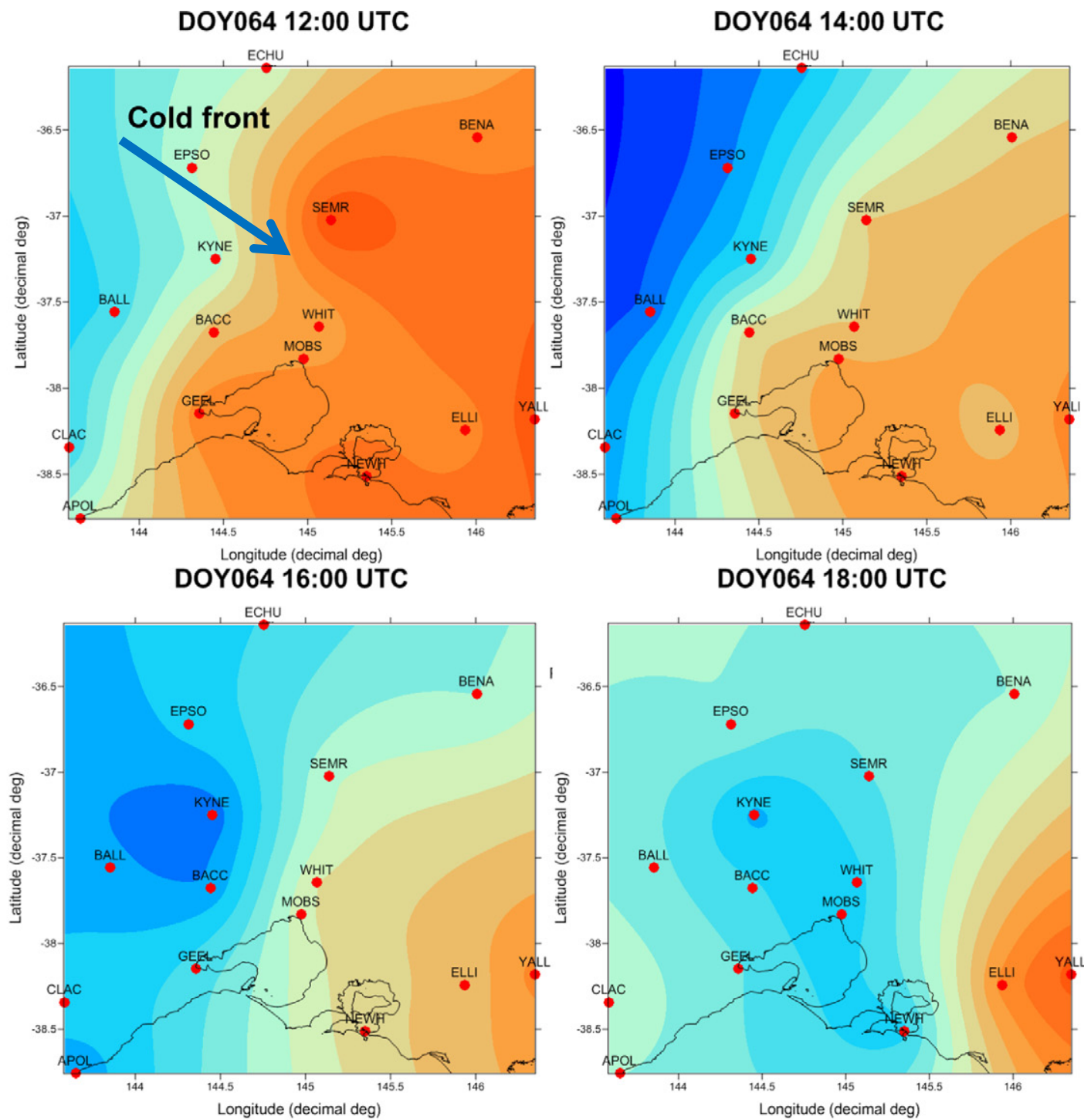

DOY064 20:00 UTC
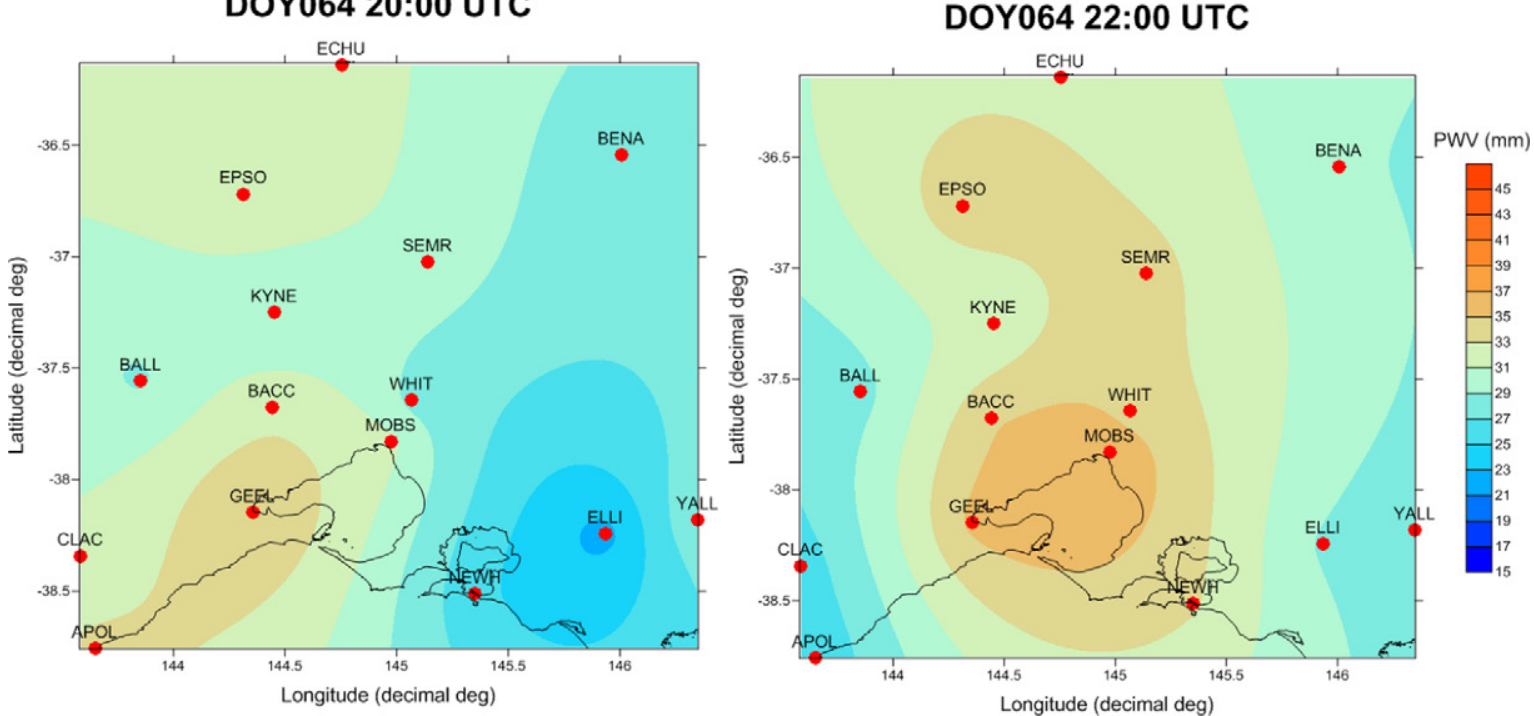

Fig. 8. Spatial distribution of water vapour content at 2-h interval during the weather front passage within Greater Melbourne on DOY 64 (5 March 2010). 
Airport and MOBS and $11 \mathrm{~m}$ between WGGA and Wagga Wagga. Comparing 1 week of GPS-PWV and RS-PWV estimates at these stations, good agreement between the GPS and the RS-PWV data has been found, with the uncertainties in the GPS-PWV of the order of 2-3 mm. This level of uncertainty agrees with previous studies (Tregoning et al., 1998; Liou and Huang, 2000; Liou et al., 2000; Liou et al., 2001; Feng et al., 2001, 2003; Wang et al., 2007; Thomas et al., 2011), demonstrating that GPS can be used with confidence as a supplementary sensor for atmospheric water vapour to complement observations from the Bureau's upper air network.

Here we present a case study to investigate potential applicability of the GPS-PWV methodology for weather forecasting, specifically for monitoring of weather fronts. In this study, 15 ground-based GPS stations from the Victorian GPS infrastructure network, i.e. GPSnet, were used (refer to Fig. 5) to examine if the GPS observations could be used to monitor the movement of weather fronts prior to severe thunderstorm occurrences. The March 2010 Melbourne storm, which brought heavy rainfall, large hail stones, strong winds and flash flooding to the state of Victoria was selected as a case study.

The March 2010 Melbourne storms were a series of storms that passed directly over Greater Melbourne. In the days before the storm, a large mass of warm, humid air had passed down from the state of Queensland, where it had caused record flooding in southern Queensland. This warm air mass clashed with a cold and dry air of low pressure system coming from the west generating severe thunderstorms. The first storm was generated in the west of Victoria in the morning on 6 March. The storm cells then extended in a southeast direction across the state between 14:00 and 17:00 AEDT (Australian Eastern Daylight time, which is UTC $+11: 00$ daylight saving), passing central Melbourne at around 14:40 AEDT. At the storm peak on 6 March, a 400-km band of rain and hail stretched across the state moving in a southeasterly direction.

Fig. 6 shows the GPS-PWV time series at the six GPSnet stations (their locations are highlighted by yellow circles in Fig. 5) over the 1week period, i.e., a few days prior to and after the storm passage. The PWV values range between $15 \mathrm{~mm}$ and $50 \mathrm{~mm}$, with some distinct variability caused by severe weather processes. It appears that the time series of PWV at all stations are consistent. The fluctuations in the PWV time series can in fact be linked to the variations in water vapour content in the troposphere, which coincide with the passing of the storm cells. The PWV increases from around $20 \mathrm{~mm}$ to $40 \mathrm{~mm}$ on DOY 063 to 064 ( 4 to 5 March 2010), corresponding to the arrival of warm and moist pre-frontal air. The warm pre-frontal air holds more water vapour than the cold post-frontal air mass. Thus, as the warm pre-frontal air passed through Greater Melbourne from west to east, the water vapour content in the atmosphere increased steadily; and when the cold and dry post-frontal air moves through, the amount of water vapour decreased from around $40 \mathrm{~mm}$ back to $20 \mathrm{~mm}$.

Fig. 7 depicts a closer snapshot of the GPS-PWV time series at six selected GPSnet stations in the western and eastern regions of Melbourne (a buffer radius of $200 \mathrm{~km}$ from Melbourne CBD) on DOY 064 (5 March 2010). As the cold front moves eastward, the first station to register a large drop in PWV was BALL, followed by APOL, BACC, MOBS, ELLI, and YALL. This phenomenon occurred at slightly different times as seen in the time series presented in Fig. 7. This shows that groundbased GPS stations located in different parts of the state can remotely sense the passage of frontal air mass. This information could be utilised to monitor and predict the course/direction of the frontal air. Furthermore, the ground-based GPS technique is capable of providing continuous observations of the storm passage with high temporal resolution. If the lateral distance between stations is known, then the velocity of the frontal air passage can be estimated. The spatial distribution of the water vapour content at 2 -h intervals during the cold frontal air passage is shown in Fig. 8 (direction of the front is shown by an arrow on the top left panel). It illustrates the movement of the cold dry post-frontal air mass as it passed eastward through Greater Melbourne. We estimated the velocity of the frontal air passage from the ground-based GPS observations and radar images and found that both estimates correspond well, providing the value of approximately $35 \mathrm{~km} / \mathrm{h}$.

\subsection{Atmospheric temperature and moisture retrieval over the Australasian region and Antarctica estimated from GPS RO and RS data}

Comparison of atmospheric temperature and moisture profiles obtained by RS and GPS RO over the Australasian region has been made over five year period from May 2006 to December 2010 at pressure levels from $1000 \mathrm{hPa}$ to $30 \mathrm{hPa}$. Data from six selected stations located in the South Indian and South Pacific Oceans (Table 1 and Fig. 1; the location of the stations is highlighted by green circles) have been examined. The number of profiles was approximately evenly distributed between TC seasons (November to April) and non-TC seasons (May to October). In general, during TC seasons (Fig. 9a) good agreement between RS and GPS RO temperature profiles (differences $< \pm 0.5^{\circ} \mathrm{C}$ ) has been found at all stations for pressure levels from 400 to $50 \mathrm{hPa}$ (at altitudes from about $6.5 \mathrm{~km}$ in the upper troposphere up to $25 \mathrm{~km}$ in the lower stratosphere, especially between 10 and $15 \mathrm{~km}$ ). For pressure levels above $400 \mathrm{hPa}$ (below $6.5 \mathrm{~km}$ altitudes), discrepancies ranging from 0.8 to $1.35^{\circ} \mathrm{C}$ were observed mainly due to high level of moisture in the lower troposphere, which affects the accuracy of algorithms for GPS RO temperature retrieval (see Rocken et al., 1997 and Kuo et al., 2004 for detail). It should be noted that the distance between RS and GPS RO profiles as well as types of RS instruments could also be

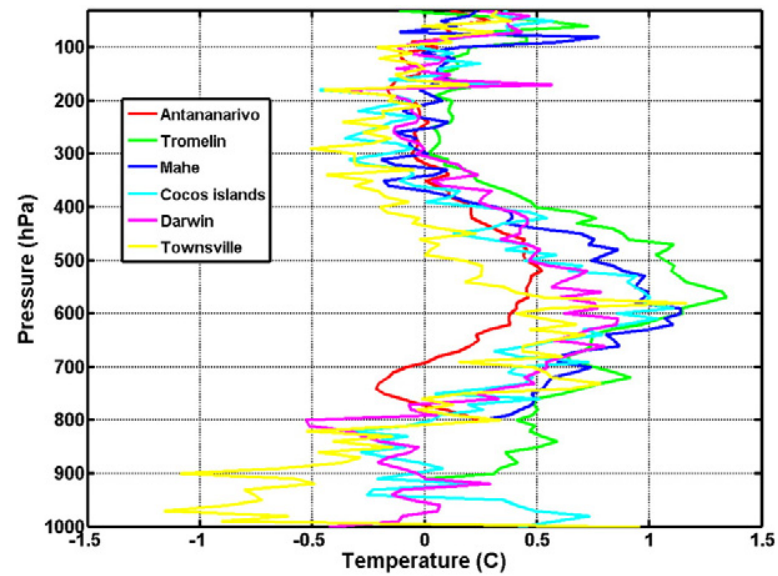

a)

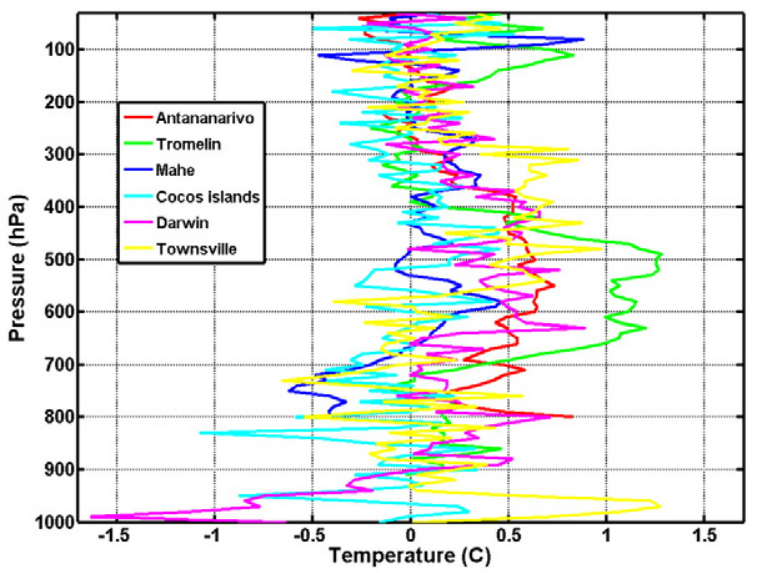

b)

Fig. 9. Difference in temperature retrievals between collocated RS and GPS RO profiles for six tropical stations (Antanarivo, Tromelin, Mahe, Cocos Island, Darwin and Townsville) for May 2006-December 2010 (a) during the Southern Hemisphere TC seasons (November to April) and (b) non-TC seasons (May to October). 


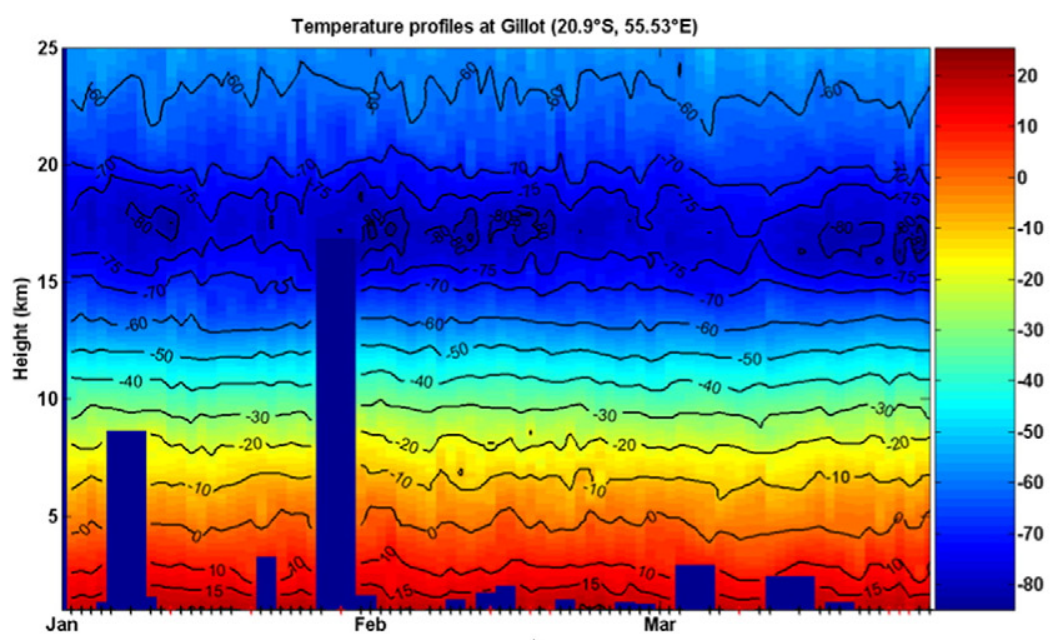

a)

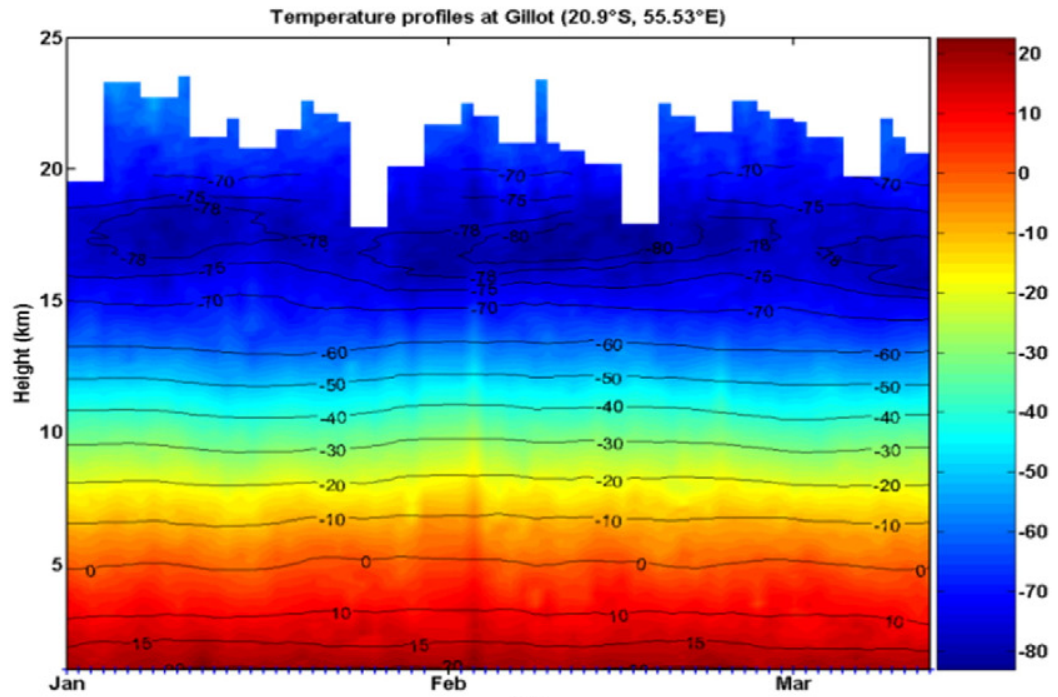

b)

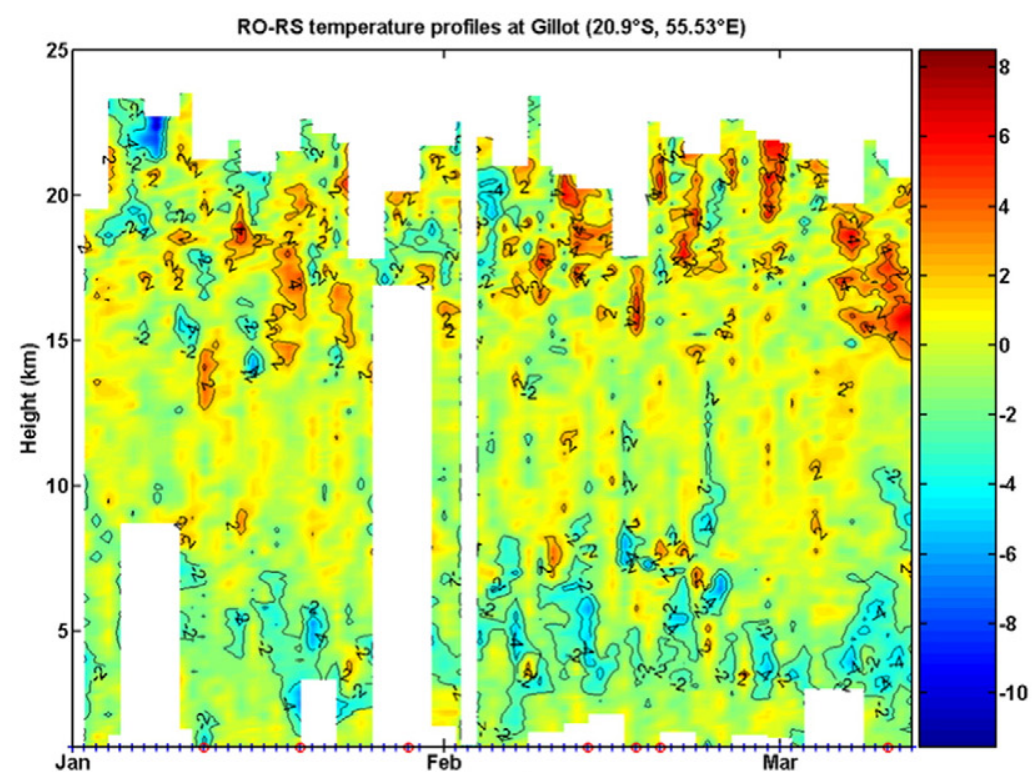

c)

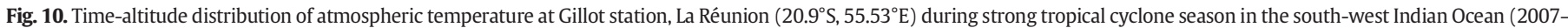
2008) derived from (a) daily GPS RO observations collocated in space (latitudes $<5^{\circ}$, longitudes $<2.5^{\circ}$ ) and (b) RS at $11: 00$ UTC and (c) the difference. 
important contributors to these differences (He et al., 2009). Similar, for non-TC seasons (Fig. 9b), good agreement between RS and GPS RO atmospheric temperature profiles $\left(< \pm 0.5^{\circ} \mathrm{C}\right)$ was observed at most pressure levels. Compared to TC seasons, the differences were reduced at pressure levels between 800 and $400 \mathrm{hPa}$, which we attribute to improving in the accuracy of temperature retrieval due to lower atmospheric moisture in May-October compared to TC seasons. Large differences in RS-GPS RO temperature observations of about $1-1.3^{\circ} \mathrm{C}$ consistently observed at Tromelin may indicate an issue with RS data at this station; however, this investigation is out of scope for this

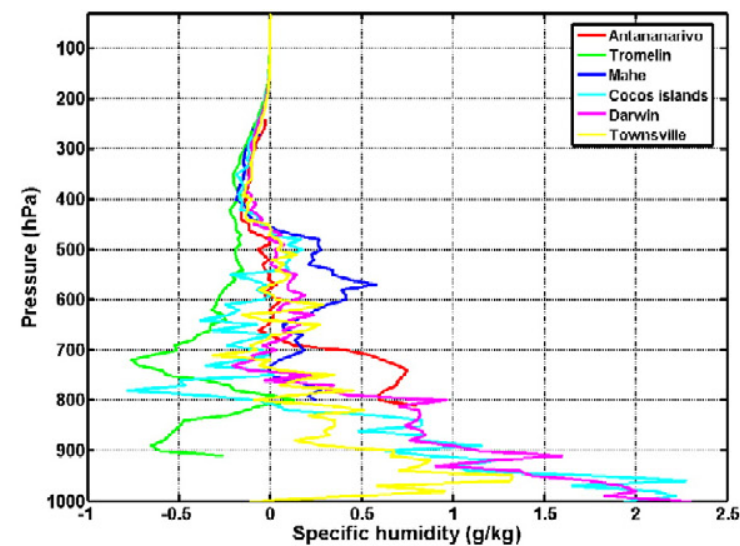

a)

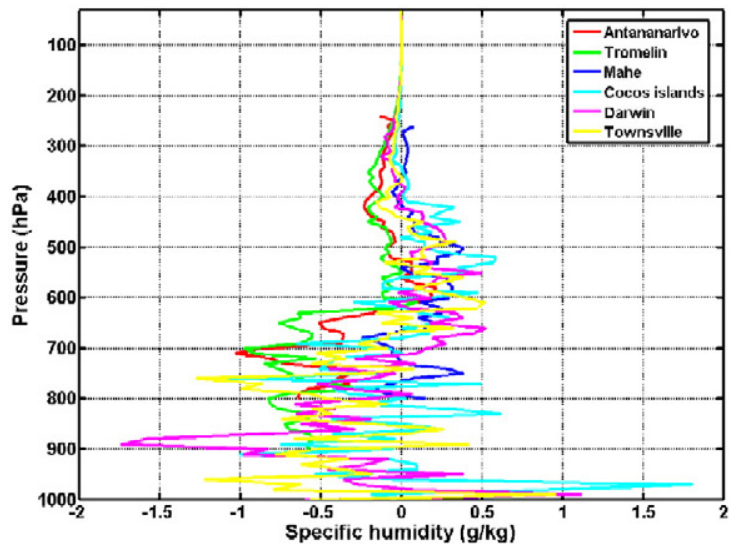

b)

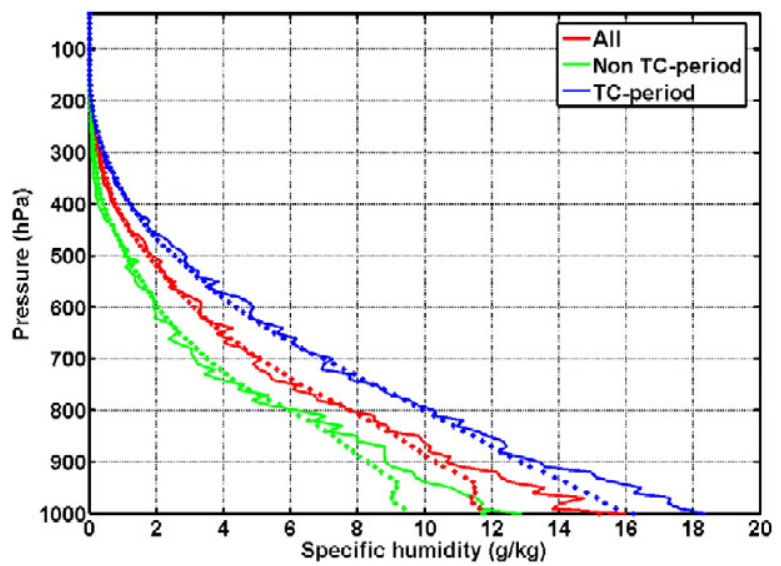

c)

Fig. 11. ( $a$ and b) Same as in Fig. 6 but for specific humidity. (c) Comparison of specific humidity derived from collocated RS (solid line) and GPS RO (dots) during the whole period of May 2006 to December 2010 (red), not-TC (green) and TC (blue) seasons for Darwin, Australia. study. Detailed comparison between daily GPS RO and RS data collocated in space (latitudes $<5^{\circ}$, longitudes $<2.5^{\circ}$ ) also demonstrates that in general temperature differences are $<2{ }^{\circ} \mathrm{C}$ with minimum differences in the upper troposphere at altitudes between 10 and $15 \mathrm{~km}$ (see example for Gillot station $\left(20.9^{\circ} \mathrm{S} 55.5^{\circ} \mathrm{E}\right)$ located in the South Indian Ocean during strong TC season 2007/2008 in Fig. 10).

In addition to temperature, atmospheric moisture profiles were also examined. Specific humidity was derived from vertical profiles of relative humidity and partial pressure of water vapour obtained by RS and GPS RO, respectively. Differences in specific humidity for TC seasons (Fig. 11a) were $<0.5 \mathrm{~g} / \mathrm{kg}$ at Darwin, Townsville, Cocos Islands and Mahe for pressure levels below $850 \mathrm{hPa}$ (at altitudes above $1.5 \mathrm{~km}$ ) and at Antanarivo and Tromelin for pressure levels below $700 \mathrm{hPa}$ (at altitudes above $2.5 \mathrm{~km}$ ). Larger differences (from 1 to $2 \mathrm{~g} / \mathrm{kg}$ for Darwin, Cocos Islands and Townsville) were observed at pressure levels above $900 \mathrm{hPa}$ (at altitudes between the surface and about $1 \mathrm{~km}$ ). Relative differences calculated as RS-GPS RO/GPS RO were $<15-20 \%$ above $400 \mathrm{hPa}$ (below $6.5 \mathrm{~km}$ ) and $<30 \%$ below $350 \mathrm{hPa}$ (above $7.5 \mathrm{~km}$ ). Comparing atmospheric moisture profiles for TC seasons and non-TC seasons (Figs. 11a and 8b, respectively), one can find that differences in values of specific humidity retrieved by RS and GPS RO were $<0.5 \mathrm{~g} / \mathrm{kg}$ for pressure levels below $700 \mathrm{hPa}$ independently of the season with exception at Tromelin where the differences ranging from 0.5 to $1 \mathrm{~g} / \mathrm{kg}$ were observed between 700 and 600 hPa pressure levels during TC period. Analysing moisture profiles, distinct difference in seasonal convective activity at Antanarivo, Darwin, Townsville and Tromelin was observed as the differences in specific humidity during non-TC and TC periods (see example for Darwin in Fig. 11c). High level of convective activity around Darwin during November to April (wet season or TC season) is well documented. On average, Darwin experiences more than 80 thunderstorms during the wet season which represents the highest thunderstorm activity in Australia (Kuleshov, 2012).

These findings are encouraging as they provide confidence that the accuracy of GPS RO-derived temperature profiles in the tropics, despite high atmospheric moisture content, is comparable with that of RSs. Thus, GPS RO data could be utilised effectively in tropical atmospheric wave studies in the upper troposphere and lower stratosphere during TC seasons in the Indian and the Pacific Oceans where RS data are available only from a few stations (Gubenko et al., 2008, 2011; Chane-Ming et al., 2014).

As for the Antarctic, six Antarctic coastal stations (Fig. 12) were selected after initial analysis of RS records based on the completeness of data records for the recent period (2000-2009) to validate the GPS RO temperature data. On average, less than $2-3 \%$ of RS data were missing

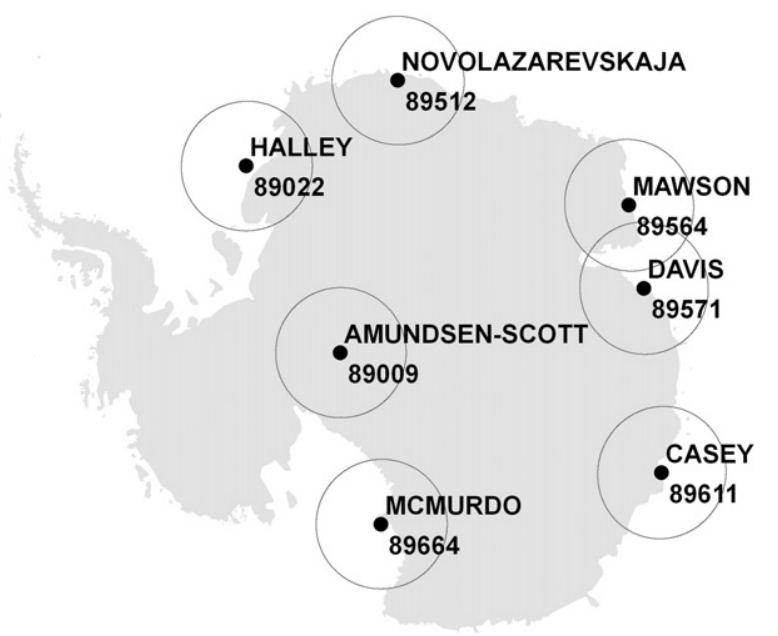

Fig. 12. Location of seven Antarctic stations used in this study to provide upper air data and $500 \mathrm{~km}$ radius circles centred at each station to encompass area of collocated GPS RO profiles. 
at nine standard pressure levels from 850 to $50 \mathrm{hPa}$ for these six stations. RS data from Amundsen-Scott station at the South Pole were also used to represent the interior areas of Antarctica, although the percentage of missing data was relatively high: $21-24 \%$ for the six standard pressure levels from 500 to $50 \mathrm{hPa}$. To enable the RS-RO comparison, GPS RO temperatures were sampled using a 500-km radius circles centred at each of the seven stations. The resulting GPS RO temperature series are referred to as the collocated RO temperature series hereafter and are compared with the corresponding in situ RS temperature series.

It was found that at all seven stations and all nine pressure levels the collocated RO temperatures are generally in good agreement with the corresponding in situ RS temperatures, in terms of both the actual values and the seasonal cycle. In the lower stratosphere to the upper troposphere (from $50 \mathrm{hPa}$ to $300 \mathrm{hPa}$ ), the collocated RO temperatures and their corresponding RS temperatures are in such good agreement that they are hardly distinguishable from each other (see example of RS (black) and GPS RO (blue) time series in Fig. 13). Similarly, very good agreement was found at other levels from $50 \mathrm{hPa}$ to $300 \mathrm{hPa}$ (not shown).

To investigate recent atmospheric temperature trends over the Antarctic, the time series of the collocated RO and RS data were examined at each pressure level for the seven stations. Linear trends estimated from the collocated RO and RS temperature series are shown in Fig. 14. Strong lower-stratospheric cooling trends have been identified at all levels from 50 to $300 \mathrm{hPa}$ for all Antarctic stations by both methods, with only two exceptions (at McMurdo $(89,664)$ RS data indicate positive trend at 50 hPa while GPS RO data indicate strong cooling, and at Novolazarevskaja $(89,512)$ RS data indicate negative temperature trend at $300 \mathrm{hPa}$ while GPS RO data indicate a weak warming trend). The 7-station-mean stratospheric cooling rates at 200 and $100 \mathrm{hPa}$ pressure levels are about $-2.6{ }^{\circ} \mathrm{C}$ and $-3.2{ }^{\circ} \mathrm{C}$ ( or $-2.1{ }^{\circ} \mathrm{C}$ and $-3.5^{\circ} \mathrm{C}$ ) per decade from the collocated GPS RO (or RS) data, respectively (see the Means in Fig. 14). Once again, we note that both GPS RO and RS data are in excellent agreement for the low-stratospheric measurements at levels from $50 \mathrm{hPa}$ to $300 \mathrm{hPa}$. In the troposphere (at levels below $300 \mathrm{hPa}$ ) both cooling and warming trends are detected at different stations depending on their geographical location; however, RO and RS data are less consistent in terms of detecting temperature trends in the lower to mid-troposphere than in the lower stratosphere. Nevertheless, for the stations in the Western Antarctica, Halley $(89,022)$ and Novolazarevskaja $(89,512)$, GPS RO data indicate warming trends in the upper troposphere at $500 \mathrm{hPa}$ and $700 \mathrm{hPa}$ pressure levels, in agreement with finding of earlier studies about rapid near-surface warming (Vaughan et al., 2001). For interior of Antarctica, cooling at all pressure levels from 50 to $500 \mathrm{hPa}$ was found (Amundsen-Scott station, 89009).
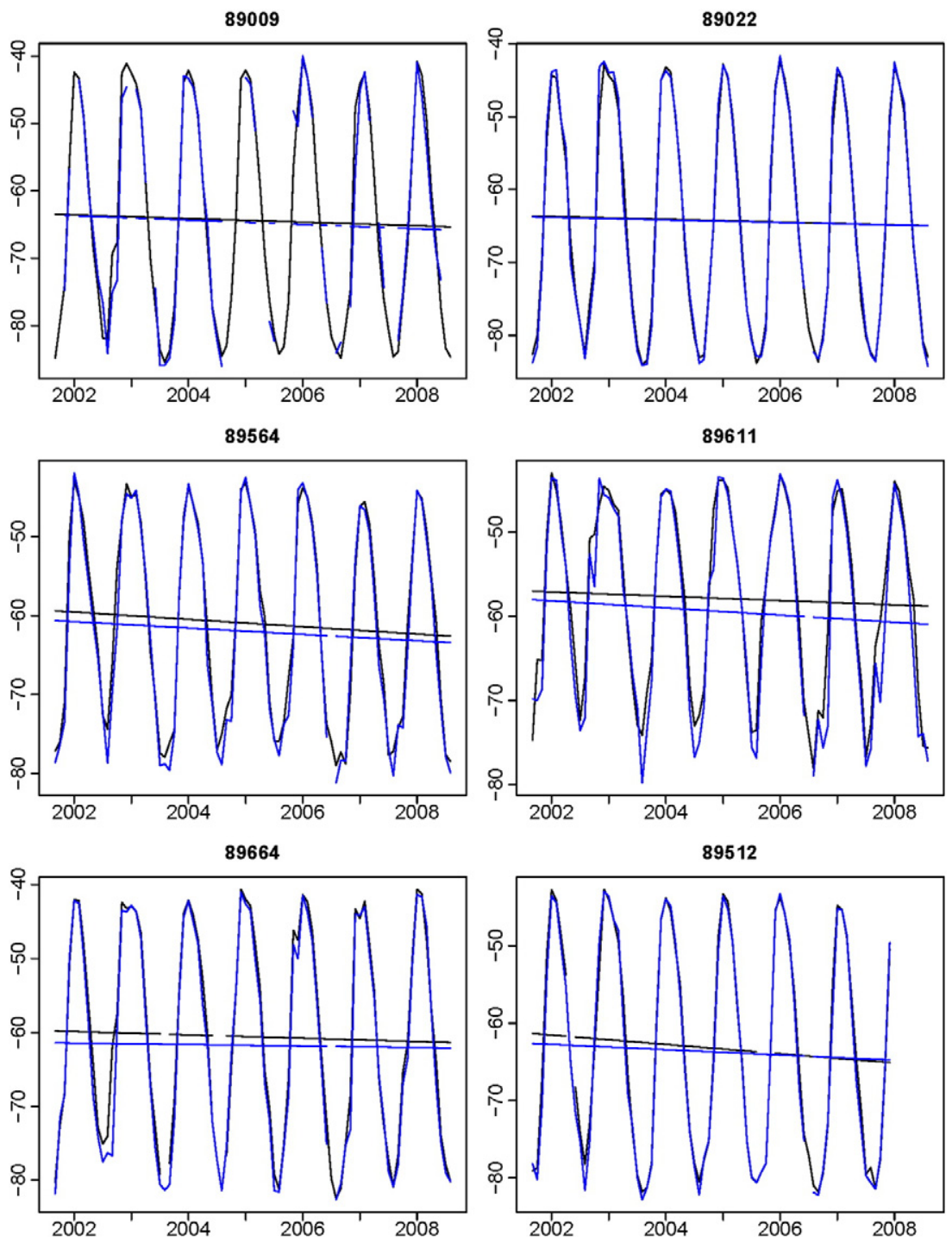

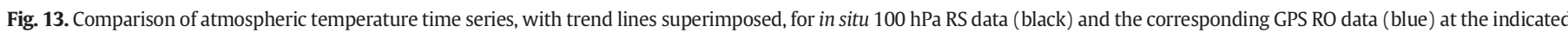
stations. 

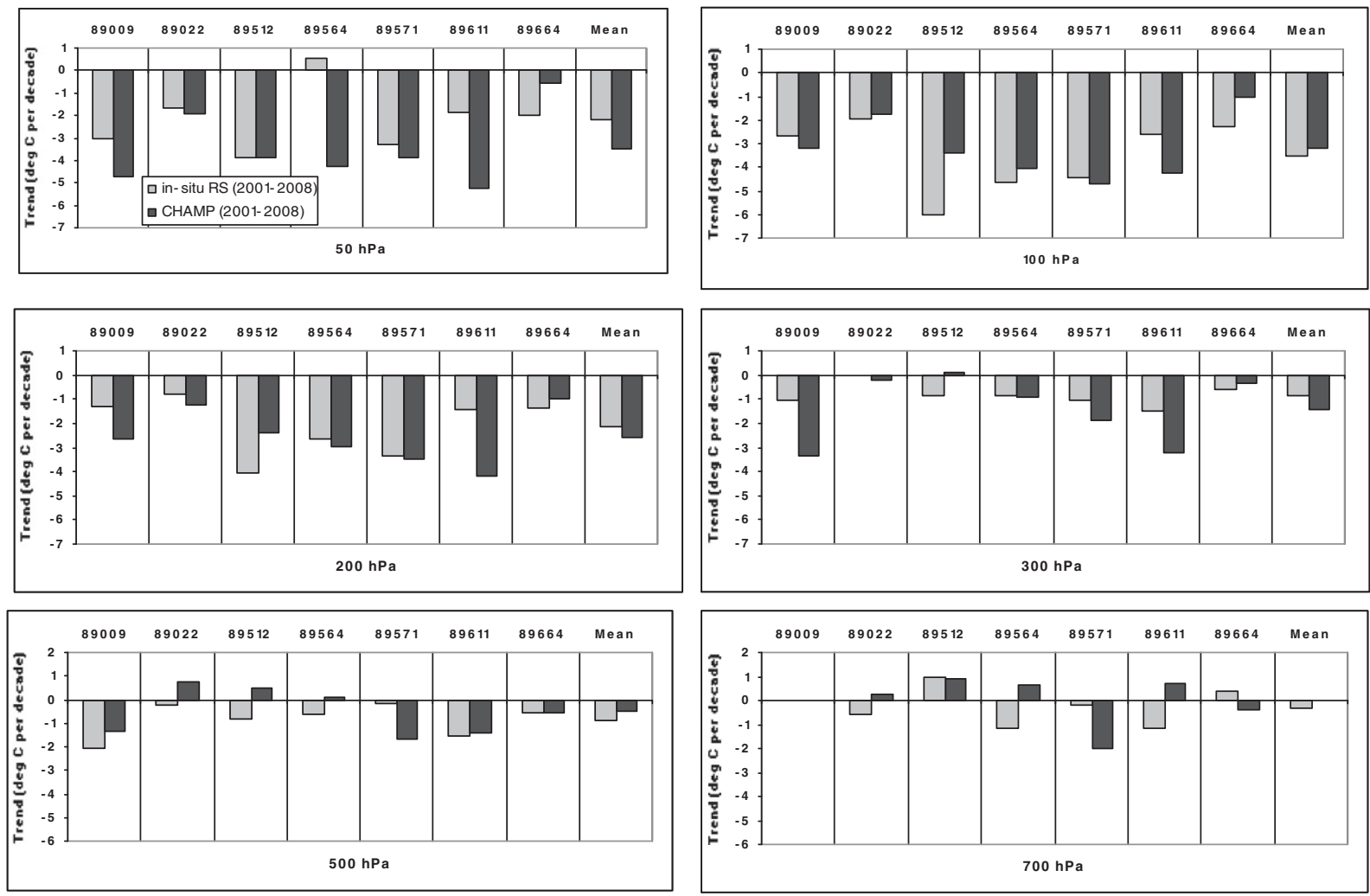

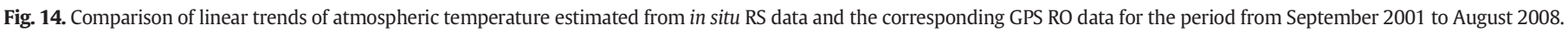
Note that station 89009 (a high elevation station) has no RS data at $700 \mathrm{hPa}$ and no bars are shown in the lower-right panel.

\section{Discussion}

In this report on recent progress in advancing climate studies in the Australasian region, we demonstrated that GPS satellite- and groundbased measurements are valuable source of meteorological data. We presented examples of distribution of atmospheric characteristics over the Indian and the Pacific Oceans, continents of Australia and Antarctica derived from GPS RO measurements and verified the accuracy of RO temperature and moisture retrieval with in situ RS data. Investigating recent atmospheric temperature trends over Antarctica, the time series of the collocated RO and RS data were examined and strong cooling in the lower stratosphere and warming through the troposphere over the Antarctica has been identified by both methodologies, with detected the strongest cooling trend of about $-3{ }^{\circ} \mathrm{C}$ per decade at $100 \mathrm{hPa}$ level. These findings demonstrate that GPS RO measurements could significantly advance climate studies for data sparse areas like the Australasian region and the Antarctic. Early study by Turner et al., 2006, through analysis of RS observations at nine stations across Antarctica for the period 1971-2003, demonstrated cooling rates of about $-0.16^{\circ} \mathrm{C}$ per decade at $100 \mathrm{hPa}$. Our findings indicate that during 2001-2008 rate of cooling at $100 \mathrm{hPa}$ level was much higher, about $-3.2{ }^{\circ} \mathrm{C}$ per decade. Our results are in agreement with outputs of climate models which indicate that recent stratospheric cooling and tropospheric warming are expected consequences of the observed increase in anthropogenic greenhouse gas concentrations (IPCC AR5, 2013).

We also evaluated potential of the Australian network of GPS stations to estimate moisture content of the atmosphere (PWV) and presented a case study for monitoring a severe thunderstorm event using GPS-PWV methodology. Comparing GPS-PWV and RS-PWV estimates at two selected stations in Victoria and NSW, good agreement between the GPS and the RS-PWV data has been found, with uncertainties in the PWV estimates in the order of 2-3 mm, which is likely as radiosonde data are accurate to about $1.2 \mathrm{~mm}$ (e.g., Feng et al., 2003; Wang and
Zhang, 2008). Using data from the 15 ground-based GPS stations from the Victorian GPS infrastructure network, we investigated the state of the atmosphere over Victoria during a significant weather event, the March 2010 Melbourne storm, and demonstrated that the GPS observations has potential for monitoring the movement of a weather front that has sharp moisture contrast. Using the ground-based GPS observations and weather radar images, we estimated a velocity of the frontal air passage and found that both estimates correspond well which demonstrates the potential of using GPS data for estimating the velocity of fronts.

These findings could have potentially important implications for enhancing the reliability and accuracy of severe weather forecasting services (Benevides et al., 2015; Shi et al., 2015; Sparta and Rahman, 2016). Accurate estimates of time of front arrival at particular localities are essential to provide early warning to public, aviation, etc., about timing of expected thunderstorm-related hazards (lightning, hail, strong winds and flash flooding) associated with passage of weather front. Lightning activity associated with thunderstorms in SE Asia and Australia is high (Kar et al., 2009; Kuleshov et al., 2009; Liou and Kar, 2010), and it is vital to accurately forecast time of thunderstorm development to provide general public with early warning. This could potentially save lives (e.g., on average, 5 to 10 people are killed by lightning in Australia annually (Lightning Protection, 2007) and significantly reduce economic damage (e.g., the total damage attributed to Sydney storm in 1999, which was the costliest natural disaster in Australian insurance history, was estimated around $\mathrm{A} \$ 2.3$ billion). It is equally important for aviation weather forecasting, with implication for improving safely of passengers and reduction of economic losses due to flights' delays or cancellations.

However, it should be noted that not all fronts have such clear moisture signature as the March 2010 Melbourne storm presented here as a case study. In general, GPS-PWV methodology may be good for monitoring dry lines as well as weather fronts with sharp moisture contrast. There is another potential problem for monitoring weather fronts using 
GPS-PWV, which is related to measuring vertically integrated water column using this technique rather than detecting near-surface moisture feature of a front. This means that for a strong front with less sharp moisture gradient, the frontal location may not be identifiable from the GPS-PWV alone so accurately as it was demonstrated in Section 3.1. Thus, in our future research, we will address this issue of refining GPS-PWV methodology for application to severe weather forecasting utilising additional surface-based and remote sensing data. A geographic information system (Chrisman, 2001) would be an invaluable tool for simultaneous analysis of multi-layered data sets of fields of atmospheric pressure and temperature, radar images, overlaid with GPS-PWV data and conventional meteorological observations to develop an operational system for weather front monitoring and enhancing severe weather forecasting services.

In this study, we extensively used F3C data. F3C, a constellation of six LEO satellites, is one of the most successful missions that utilised GPS radio signals for meteorology and climate application. It is in operational use since 2006. Success of the F3C mission encouraged the development of the follow up mission-FORMOSAT-7/COSMIC-2 (F7C2) constellation of 12 LEO satellites. The first launch of six satellites of the low inclination constellation is planned for 2016 and the second launch of another six satellites into the high inclination orbits-for 2018. Consequently, significant increase in temporal and spatial coverage of the Australasian region by the RO events from $\mathrm{F} 3 \mathrm{C}$ and $\mathrm{F} 7 \mathrm{C} 2$ constellations with multiple Global Navigation Satellite Systems (GNSS) systems (i.e. GPS, GLONASS, Galileo and QZSS) is expected.

To summarise, in the near future, with further expansion of GNSS system, it is expected that GNSS satellite- and ground-based measurements would be able to provide much larger (an order of magnitude) amount of quality atmospheric data which in turn could significantly advance studies on climate analysis and monitoring in the Australasian region.

\section{Concluding remarks}

GPS RO technique has been recognised as an emerging technique for Earth's atmospheric observation. Atmospheric profiles derived from GPS RO observations provide valuable information about the state of the atmosphere over the oceans where upper air data from conventional meteorological observations are particularly scarce. With the recent GPS modernisation and new global and regional GNSS systems in the near future, next-generation RO missions will have opportunity and capability to utilise signals (in over ten different frequencies) from more than a hundred of GNSS satellites. As a consequence, the resolution, quantity and quality of the GNSS RO observations will be improved significantly, and the data will have significant impact on various climatological and meteorological applications. Valuable information derived from GNSS RO atmospheric profiles would be utilised to improve the accuracy of weather forecasting and climate studies. Similarly, data from GNSS ground-based stations (e.g., the Australian ground-based GPS/GNSS reference stations network) will provide accurate estimates of atmospheric moisture which could have positive impact on skill of weather forecasting and in longer terms assist with improving our understanding of the regional climate processes.

\section{Acknowledgments}

This work was partially supported by the RMIT Foundation and the Malcolm Moore Industry Research Grant French StraDyVariUS ANR13-BS06-0011-01 grant, and Taiwan NSC 102-2111-M-008-027 and NSC 102-2221-E-008-034 grants.

\section{References}

Benevides, P., Catalao, J., Miranda, P.M.A., 2015. On the inclusion of GPS precipitable water vapour in the nowcasting of rainfall. Nat. Hazards Earth Syst. Sci. 15, 2605-2616. http://dx.doi.org/10.5194/nhess-15-2605-2015.
Bevis, M., Businger, S., Herring, T.A., Rocken, C., Anthes, R.A., Ware, R.H., 1992. GPS meteorology: remote sensing of atmospheric Water vapor using the global positioning system. J. Geophys. Res. 99 (14), 787-801.

Bevis, M., Businger, S., Chiswell, S., Herring, T.A., Anthes, R.A., Rocken, C., Ware, R.H., 1994 GPS meteorology-mapping zenith wet delays onto precipitable Water. J. Appl. Meteorol. 33, 379-386.

Bock, O., Nuret, M., 2009. Verification of NWP model analyses and radiosonde humidity data with GPS precipitable water vapor estimates during AMMA. Weather Forecast. 24, 1085-1101.

Bromwich, D.H., Nicolas, J.P., Monaghan, A.J., Lazzara, M.A., Keller, L.M., Weidner, G.A. Wilson, A.B., 2012. Central West Antarctica among the most rapidly warming regions on earth. Nat. Geosci. 6 (2), 139-145.

Budretsky, A.B., 1984. New absolute minimum of air temperature. Bull. Soviet Antarctic Expedition (in Russian). Gidrometeoizdat, Leningrad, p. 105.

Chane-Ming, F., Ibrahim, C., Jolivet, S., Keckhut, P., Liou, Y.-A., Kuleshov, Y., 2014. Observation and a numerical study of gravity waves during tropical cyclone Ivan (2008). Atmos. Chem. Phys. 14, 641-658.

Chrisman, N.R., 2001. Exploring Geographic Information Systems. John Wiley (270 pp.).

Davis, J.L., Herring, T.A., Shapiro, I.I., Rogers, A.E.E., Elgered, G., 1985. Geodesy by radio interferometry: effects of atmospheric modeling errors on estimates of baseline length. Radio Sci. 20, 1593-1607.

Department of Environment and Primary Industries, 2013. Vicmap Position-GPSnet. http://www.dse.vic.gov.au/property-titles-and-maps/maps-imagery-and-data/data/ gpsnet.

Dhaka, S.K., Kumar, V., Choudhary, R.K., Shu-Peng, Ho, Takahashi, M., Yoden, S., 2015. Indications of a strong dynamical coupling between the polar and tropical regions during the sudden stratospheric warming event January 2009, based on COSMIS/ FORMOSAT-3 satellite temperature data. Atmos. Res. 166, 60-69.

Feng, Y., Bai, Z., Fang, P., Williams, A., 2003. GPS water vapour experimental results from observations of the Australian regional GPS Network. Geomatics Res. Australas. 79, 21-41.

Feng, Y., Bai, Z., Williams, A., 2001. GPS water vapour experimental results from observations of the Australian Regional GPS Network (ARGN). 2001-A Spatial Odyssey: 42nd Australian Surveyors Congress, Brisbane, Australia.

Fong, C.J., Shiau, W.T., Lin, C.T., Kuo, T.C., Chu, C.H., Yang, S.K., Yen, N., Chen, S.S., Kuo, Y.H., Liou, Y.A., Chi, S., 2008a. Constellation deployment for FORMOSAT-3/COSMIC mission. IEEE Trans. Geosci. Remote Sens. 46 (11), 3367-3379. http://dx.doi.org/10.1109/ TGRS.2008.2005202.

Fong, C.J., Yang, S.-K., Chu, C.-H., Huang, C.-Y., Yeh, J.-J., Lin, C.T., Kuo, T.C., Liu, T.-Y., Yen, N., Chen, S.-S., Kuo, Y.H., Liou, Y.A., Chi, S., 2008b. FORMOSAT-3/COSMIC constellation spacecraft system performance: after one year in orbit. IEEE Trans. Geosci. Remote Sens. 46 (11), 3380-3394. http://dx.doi.org/10.1109/ TGRS.2008.2005203.

Fu, E., Zhang, K., Wu, F., Xu, X., Marion, K., Rea, A., et al., 2007. An evaluation of GNSS radio occultation technology for Australian meteorology. J. Glob. Positioning Syst. 6, 74-79.

Graham, N.E., 1994. Decadal-scale climate variability in the tropical and North Pacific during the 1970s and 1980s: observations and model results. Clim. Dyn. 10, $135-162$.

Gubenko, V.N., Pavelyev, A.G., Salimzyanov, R.R., Pavelyev, A.A., 2011. Reconstruction of internal gravity wave parameters from radio occultation retrievals of vertical temperature profiles in the Earth's atmosphere. Atmos. Meas. Tech. 10, 2153-2162. http:// dx.doi.org/10.5194/amt-4-2153-2011.

Gubenko, V.N., Pavelyev, A.G., Andreev, V.E., 2008. Identification of wave origin of temperature fluctuations and determination of the intrinsic frequency of internal gravity waves in the Earth's stratosphere derived from radio occultation data. J. Geophys. Res. 113 (1-9), D08109. http://dx.doi.org/10.1029/2007JD008920.

He, W., Ho, S.-P., Chen, H., Zhou, X., Hunt, D., Kuo, Y.-H., 2009. Assessment of radiosonde temperature measurements in the upper troposphere and lower stratosphere using COSMIC radio occultation data. Geophys. Res. Lett. 36, L17807. http://dx.doi.org/10. 1029/2009gl038712.

Heise, S., Wickert, J., Beyerle, G., Schmidt, T., Reigberet, Ch., 2006. Global monitoring of tropospheric water vapor with GPS radio occultation aboard CHAMP. Adv. Space Res. 37 (12), 2222-2227.

IPCC AR5, 2013. Working Group I contribution to the IPCC Fifth Assessment Report Climate Change 2013: The Physical Science Basis. Summary for Policymakers (http:// www.climate2013.org/images/uploads/WGI_AR5_SPM_brochure.pdf).

Jade, S., Vijayan, M.S.M., Gaur, V.K., Prabhu, T.P., Sahu, S.C., 2005. Estimates of precipitable water vapour from GPS data over the Indian subcontinent. J. Atmos. Sol. Terr. Phys. 67, 623-635.

Kar, S.K., Liou, Y.-A., Ha, K.-J., 2009. Aerosol effects on the enhancement of cloud-toground lightning over major urban areas of South Korea. Atmos. Res. 92 (1), 80-87. http://dx.doi.org/10.1016/j.atmosres.2008.09.004.

King, J.C., 1994. Recent climate variability in the vicinity of the Antarctic peninsula. Int. J. Climatol. 14, 357-369.

Kuleshov, Y., 2004. Seasonal and latitudinal variations of lightning ground flash activity in Australia. Aust. Meteorol. Mag. 53, 197-204.

Kuleshov, Y., 2012. Thunderstorm and lightning climatology (Chapter 4, in book) Modern Climatology. Intech, pp. 85-120 (ISBN: 979-953-307-337-7).

Kuleshov, Y., Mackerras, D., Darveniza, M., 2009. Spatial distribution and frequency of thunderstorms and lightning in Australia (Chapter 8, in book) In: Betz, H.D. Schuman, U., Laroche, P. (Eds.), Lightning: Principles, Instruments and Applications. Springer, pp. 189-209 http://dx.doi.org/10.1007/978-1-4020-9079-0_8.

Kuleshov, Y., McGree, S., Jones, D., Charles, A., Cottrill, A., Prakash, B., Atalifo, T., Nihmei, S., Seuseu, F.L.S.K., 2014. Extreme weather and climate events and their impacts on island countries in the Western Pacific: cyclones, floods and droughts. Atmos. Climate Sci. 4, 803-818. http://dx.doi.org/10.4236/acs.2014.45071. 
Kumar, V., Dhaka, S.K., Reddy, K.K., Gupta, A., Prasad, S.B.S., Panwar, V., Singh, N., Ho, S.-P., Takahashi, M., 2014. Impact of quasi-biennial oscillation on the inter-annual variability of the tropopause height and temperature in the tropics: a study using COSMIC/ FORMOSAT-3 observations. Atmos. Res. 139, 62-70.

Kuo, Y.-H., Schreiner, W.S., Wang, J., Rossiter, D., Zhang, Y., 2005. Comparison of GPS radio occultation soundings with radiosondes. Geophys. Res. Lett. 32, L05817. http://dx.doi. org/10.1029/2004GL021443.

Kuo, Y.-H., Wee, T.K., Sokolovskiy, S., Rocken, C., Schreiner, W., Hunt, D., Anthes, R.A., 2004. Inversion and error estimation of GPS radio occultation data. J. Meteorol. Soc. Jpn. 82B, 507-531.

Lightning protection, 2007. Australian Standard/New Zealand Standard 1768:2007 (Prepared by the Standards Australia Committee EL-24) (199 pp.).

Liou, Y.-A., Huang, C.-Y., 2000. GPS observations of PW during the passage of a typhoon. Earth Planets Space 52 (10), 709-712.

Liou, Y.-A., Kar, S.K., 2010. Study of cloud-to-ground lightning and precipitation and their seasonal and geographical characteristics over Taiwan. Atmos. Res. 95, 115-122. http://dx.doi.org/10.1016/j.atmosres.2009.08.016.

Liou, Y.A., Pavelyev, A.G., Matugov, S.S., Yakovlev, O.I., Wickert, J., 2010. Radio Occultation Method for Remote Sensing of the Atmosphere and Ionosphere (ISBN 978-953-761960-2, 176 pp.) I-Tech Education and Publishing KG, Croatia (http://www.intechopen. com/books/radio-occultation-method-for-remote-sensing-of-the-atmosphere-andionosphere).

Liou, Y.-A., Huang, C.-Y., Teng, Y.-T., 2000. Precipitable water observed by groundbased GPS receivers and microwave radiometry. Earth Planets Space 52 (6) 445-450.

Liou, Y.-A., Pavelyev, A.G., Liu, S.F., Pavelyev, A.A., Yen, N., Huang, C.Y., Fong, C.J., 2007. FORMOSAT-3 GPS radio occultation mission: preliminary results. IEEE Trans. Geosci. Remote Sens. 45 (10), 3813-3826. http://dx.doi.org/10.1109/TGRS.2007.903365.

Liou, Y.-A., Teng, Y.-T., Van Hove, T., Liljegren, J., 2001. Comparison of precipitable wate observations in the near tropics by GPS, microwave radiometer, and radiosondes. J. Appl. Meteorol. 40 (1), 5-15.

Nicholls, N., 1993. ENSO, drought and flooding rain in Southeast Asia. South-east Asia's Environmental Future. The Search for Sustainability. Oxford Univ. Press, pp. 154-175 (1993, 456 pp.)

Pavelyev, A.G., Zhang, K., Liou, Y.-A., Pavelyev, A.A., Wang, C.S., Wickert, J., Schmidt, T. Kuleshov, Y., 2013. Principle of locality and analysis of radio occultation data. IEEE Trans. Geosci. Remote Sens. 51 (6), 3240-3249. http://dx.doi.org/10.1109/TGRS. 2012.2225629.

Rao, D.N., Ratnam, M.V., Mehta, S., Nath, D., Basha, S.G., Rao, V.V.M.J., Murthy, B.V.K Tsuda, T, Nakamura, K, 2009. Validation of the COSMIC radio occultation data ove Gadanki: a tropical region. Terr. Atmos. Ocean. Sci. 20, 50-70.

Rocken, C., Anthes, R., Exner, M., Hunt, D., Sokolovskiy, S., Ware, R., et al., 1997. Analysis and validation of GPS/MET data in the neutral atmosphere. J. Geophys. Res. 102, 29849-29866.

Rocken, C., Ware, R.H., Van Hove, T., Solheim, F., Alber, C., Johnson, J., 1993. Sensing atmospheric Water vapour with the global positioning system. Geophys. Res. Lett. 20, 2631-2634.

Saji, N.H., Goswami, B.N., Vinayachandran, P.N., Yamagata, T., 1999. A dipole mode in the tropical Indian Ocean. Nature 401, 360-363.

Santhi, Y.D., Ratnam, M.V., Dhaka, S.K., Rao, S.V., 2014. Global morphology of convection indices observed using COSMIC GPS RO satellite measurements. Atmos. Res. 137, 205-215.

Seko, H., Shimada, S., Nakamura, H., Kato, T., 2000. Three dimensional distribution of water vapor estimated from tropospheric delay of GPS data in a mesoscale precipitation system of the Baiu front. Earth Planets Space 52, 927-933.
Shi, J., Xu, C., Guo, J., Gao, Y., 2015. Real-time GPS precise point positioning-based precipitable water vapor estimation for rainfall monitoring and forecasting. IEEE Trans. Geosci. Remote Sens. 53 (6), 3452-3459.

Sparta, W., Rahman, R., 2016. Spatial interpolation of GPS PWV and meteorological variables over the west coast of peninsular Malaysia during 2013 Klang Valley flash flood. Atmos. Res. 168, 205-219.

Steig, E., Schneider, D.P., Rutherford, S.D., Mann, M.E., Comiso, J.C., Shindell, D.T., 2009. Warming of the Antarctic ice-sheet surface since the 1957 International Geophysical Year. Nature 457, 459-462.

Thomas, I.D., King, M.A., Clarke, P.J., Penna, N.T., 2011. Precipitable water vapor estimates from homogeneously reprocessed GPS data: an intertechnique comparison in Antarctica. J. Geophys. Res.-Atmos. 116, 2011.

Thorne, P.W., Parker, D.E., Tett, S.F.B., Jones, P.D., Mc Carthy, M., Coleman, H., Brohan, P., 2005. Revisiting radiosonde upper-air temperatures from 1958 to 2002. J. Geophys. Res. 110, D18105. http://dx.doi.org/10.1029/2004JD005753.

Tregoning, P., Boers, R., O'Brien, D., Hendy, M., 1998. Accuracy of absolute precipitable water vapor estimates from GPS observations. J. Geophys. Res.-Atmos. 103, 28701-28710.

Trenberth, K.E., 1997. The definition of El Niño. Bull. Am. Meteorol. Soc. 78, 2771-2777.

Turner, J., Lachlan-Cope, T.A., Colwell, S., Marshall, G.J., Connolley, W.M., 2006. Significant warming of the Antarctic winter troposphere. Science 311, 1914-1917.

Vaughan, D.G., Bamber, J.L., Giovinetto, M., Russell, J., Cooper, A.P.R., 1999. Reassessment of net surface mass balance in Antarctica. J. Clim. 12, 933-945.

Vaughan, D.G., Marshall, G.J., Connolley, W.M., King, J.C., Mulvaney, R., 2001. Climate change: devil in the detail. Science 293, 1777-1779. http://dx.doi.org/10.1126/ science. 1065116.

Wang, J.H., Zhang, L.Y., 2008. Systematic errors in global radiosonde precipitable water data from comparisons with ground-based GPS measurements. J. Clim. 21, 2218-2238.

Wang, J.H., Zhang, L.Y., Dai, A., Van Hove, T., Van Baelen, J., 2007. A near-global, 2-hourly data set of atmospheric precipitable water from ground-based GPS measurements. J. Geophys. Res.-Atmos. 112, D11107. http://dx.doi.org/10.1029/2006JD007529.

Wickert, J., 2004. Comparison of vertical refractivity and temperature profiles from CHAMP with radiosonde measurements. Danish Meteorological Institute, Scientific Report 04-09 (27 pp.).

Wickert, J., Reigber Ch. Beyerle, G, König R Marquardt, C. Schmidt, T. Grunwaldt, L. Galas, R., Meehan, T.K., Melbourne, W.G., Hocke, K., 2001. Atmosphere sounding by GPS radio occultation: first results from CHAMP. Geophys. Res. Lett. 28 (17), 3263-3266.

Wickert, J., Schmidt, T., Michalak, G., Heise, S., Arras, C., Beyerle, G., et al., 2009. GPS radio occultation with CHAMP, GRACE-A, SAC-C, TerraSAR-X, and FORMOSAT-3/COSMIC: brief review of results from GFZ (in book) In: Steiner, A., Pirscher, B., Felsche, U., Kirchengast, G. (Eds.), New Horizons in Occultation Research. Springer-Verlag, Berlin Heidelberg, pp. 3-15 http://dx.doi.org/10.1007/978-3-642-00321-9.

Zhang, K., Fu, E., Silcock, D., Wang, Y., Kuleshov, Y., 2011. An investigation of atmospheric temperature profiles in the Australian region using collocated GPS radio occultation and radiosonde data. Atmos. Meas. Tech. 4, 2087-2092. http://dx.doi.org/10.5194/ amt-4-2087-2011.

Zhang, M., Ni, Y.Q., Zhang, F.Q., 2007. Variational assimilation of GPS precipitable water vapor and hourly rainfall observations for a meso-beta scale heavy precipitation event during the 2002 Mei-Yu season. Adv. Atmos. Sci. 24, 509-526.

Zhang, Y., Wallace, J.M., Battisti, D.S., 1997. ENSO-like interdecadal variability: 1900-1993. J. Clim. 10, 1004-1020.

Zillman, J.W., 2001. A Hundred Years of Science and Service. Bureau of Meteorology, Melbourne (2001, 20 pp.) 